\title{
Major Bioactive Alkaloids and Biological Activities of Tabernaemontana Species (Apocynaceae)
}

\author{
Clarissa Marcelle Naidoo ${ }^{1}{ }^{(}$, Yougasphree Naidoo $^{1}$, Yaser Hassan Dewir ${ }^{2,3, * \mathbb{C}}$, Hosakatte Niranjana Murthy ${ }^{4} \mathbb{D}$, \\ Salah El-Hendawy ${ }^{2,5}$ and Nasser Al-Suhaibani ${ }^{2}$ \\ 1 School of Life Sciences, Westville Campus, University of KwaZulu-Natal, Private Bag X54001, \\ Durban 4000, South Africa; naidooclarissa5@gmail.com (C.M.N.); naidooy1@ukzn.ac.za (Y.N.) \\ 2 Plant Production Department, College of Food and Agriculture Sciences, King Saud University, P.O. Box 2460, \\ Riyadh 11451, Saudi Arabia; mosalah@ksu.edu.sa (S.E.-H.); nsuhaib@ksu.edu.sa (N.A.-S.) \\ 3 Department of Horticulture, Faculty of Agriculture, Kafrelsheikh University, Kafr El-Sheikh 33516, Egypt \\ 4 Department of Botany, Karnatak University, Dharwad 580003, India; hnmurthy60@gmail.com \\ 5 Department of Agronomy, Faculty of Agriculture, Suez Canal University, Ismailia 41522, Egypt \\ * Correspondence: ydewir@ksu.edu.sa
}

Citation: Naidoo, C.M.; Naidoo, Y.; Dewir, Y.H.; Murthy, H.N.;

El-Hendawy, S.; Al-Suhaibani, N.

Major Bioactive Alkaloids and

Biological Activities of

Tabernaemontana Species

(Apocynaceae). Plants 2021, 10, 313

https://doi.org/10.3390/

plants10020313

Academic Editor: Milan Stankovic

Received: 31 December 2020

Accepted: 29 January 2021

Published: 5 February 2021

Publisher's Note: MDPI stays neutral with regard to jurisdictional claims in published maps and institutional affiliations.

Copyright: (c) 2021 by the authors. Licensee MDPI, Basel, Switzerland. This article is an open access article distributed under the terms and conditions of the Creative Commons Attribution (CC BY) license (https:/ / creativecommons.org/licenses/by/ $4.0 /)$.

\begin{abstract}
Several species belonging to the genus Tabernaemontana have been well researched and utilized for their wide-ranging biological activities. A few of the most prominent species include Tabernaemontana divaricata, Tabernaemontana catharinensis, Tabernaemontana crassa, and Tabernaemontana elegans. These species and many others within the genus often display pharmacological importance, which is habitually related to their chemical constituents. The secondary metabolites within the genus have demonstrated huge medicinal potential for the treatment of infections, pain, injuries, and various diseases. Regardless of the indispensable reports and properties displayed by Tabernaemontana spp., there remains a wide variety of plants that are yet to be considered or examined. Thus, an additional inclusive study on species within this genus is essential. The current review aimed to extensively analyze, collate, and describe an updated report of the current literature related to the major alkaloidal components and biological activities of species within the genus Tabernaemontana.
\end{abstract}

Keywords: alkaloids; Apocynaceae; biological activity; pharmacological properties; Tabernaemontana

\section{Introduction}

The genus Tabernaemontana belonging to the family Apocynaceae was named by a German physician and botanist, J. Th. Muller [1]. At present, approximately 100 species belonging to this genus have been distributed in tropical and subtropical regions around the world, including Africa, Asia, Oceania, and the Americas [2]. Tabernaemontana species consists of flowering shrubs and small-medium-sized trees, which habitually grow in the savannahs, rocky outcrops, and forest understories [3]. Characteristic features of the genus include tubular white flowers, follicular fruit with seeds embedded within a yellow to reddish aril, and a milky or watery latex exudate, which is often found in wounded species [4]. Due to the latex content, plants within this genus are usually called "milkweed" and are often used for their biological activities $[2,5,6]$. Plants within the genus Tabernaemontana obtain a profusely high alkaloid content, usually displaying pharmacological activity [2]. Furthermore, monoterpene indole and bisindole alkaloids are the major classes of alkaloids within the genus, and other compounds include terpenes, lactones, steroids, phenolics, and flavonoids [1]. Over 67 species have been investigated for indole alkaloids, of which 470 isolations of approximately 240 structurally different bases have been detected [2,3,7].

A few of the most intensively studied Tabernaemontana species include T. divaricata, also known as "Crape Jasmine", which occurs in the tropical regions of southern China, India, and Thailand [8]. Crape Jasmine is intensively utilized as an aphrodisiac, tonic, and a purgative [8]. According to Van Beek et al. [1], in western India, latex is used for 
inflammation and wound healing. T. catharinensis, usually recognized as "Snakeskin", is a small tree native to Brazil and is found in many surrounding countries [9]. This species is used frequently in traditional medicine for the removal of warts and as an antidote for snakebites [10]. Tabernaemontana crassa, also known as "Adam's apple flower", occurs in Africa, DR Congo, and north of Angola [11]. A substantial number of alkaloids have been identified in T. crassa, possibly suggesting its medicinal properties [1]. This species has several traditional uses: a local anesthetic; and in the treatment of malaria, wounds, sores, and abscesses [1,12]. Tabernaemontana corymbosa, locally, referred to as "Jelutong badak", is a wild shrub or small tree that primarily occurs in Indonesia, Laos, Thailand, Vietnam, Malaysia, and China [13]. All parts of T. corymbosa are regularly used in ethnobotany [13-15]. In South Africa, the genus is represented by two species: Tabernaemontana ventricosa and T. elegans $[16,17]$. Tabernaemontana ventricosa, frequently termed the "Forest toad tree", is a small-medium-sized tree that is native to Africa [18]. All parts of the tree contain a white milky latex substance [18]. Due to other better-known Tabernaemontana species, little or no research has been carried out on T. ventricosa. However, despite the lack of research, T. ventricosa remains ethnomedicinally used in South Africa to promote wound healing, aid in pain relief, treat high blood pressure, reduce fever, and contains antiamoebic activity $[18,19]$. Tabernaemontana elegans, commonly called the "Toad tree", is a small tree found in river fringes and coastal scrub forests [20]. In Zimbabwe and Mozambique, the fruit is regularly eaten when ripe, as it is deemed to contain medicinal properties [1]. The coagulated latex is used as a preventative measure for bleeding (Styptic), root decoctions are ingested for pulmonary disease and chest pains, and seeds and stem bark are used to treat heart disease and cancer $[1,21,22]$.

Currently, the massive potential of countless Tabernaemontana species has led to the investigation of various plant crude extracts, fractionations, chemical constituents, and isolated compounds [2]. These novel assessments are exceedingly valuable as it may be applied for the detection of innovative compounds that could be used to improve the pharmacological background of this genus [2,7]. However, despite the consistent usage of Tabernaemontana species in traditional medicine systems and the confirmation of their biological activities, various species are yet to be investigated for their chemical properties and biological activities [2,3]. The review will explicitly elaborate on species within Tabernaemontana, with emphasis on their biological activities that have been recently published.

\section{Major Bioactive Components and Biological Activities of Tabernaemontana Species}

The Tabernaemontana genus acquires a generous source of monoterpene indole alkaloids, which are derived from the aromatic acid tryptophan and the iridoid terpene secologanin [6]. Monoterpene indole alkaloids have been found to exhibit numerous skeletal types, namely seco-tabersonine alkaloids, bis-vobtusine-type alkaloids, and bis-vosbsinylibogan indole alkaloids [3,11]. Currently, there are $>1800$ structurally diverse monoterpenederived indole alkaloids that have been classified within Tabernaemontana [3,6]. Another major class of alkaloids identified in this genus is heterodimeric bis-indole alkaloids [6]. This compound has been characterized by the biosynthesis of dimeric structures from two independent-class alkaloids [6]. A summary of the major alkaloids isolated from species within the genus Tabernaemontana is displayed in Table 1. 
Table 1. Major alkaloids isolated within the genus Tabernaemontana.

\begin{tabular}{|c|c|c|}
\hline Species & Reported Alkaloids & References \\
\hline Tabernaemontana angulata & Voacangine, voronaridine & {$[23]$} \\
\hline Tabernaemontana catharinensis & $\begin{array}{l}\text { Isovoacangine, coronaridine, heyneanine, 16-epiaffinine, catharinensine, } \\
\text { 16-decarbo-methoxyvoacamine, conodurine, ibogamine, tabernanthine, voacangine, } \\
\text { 3-hydroxyvoacangine, 3-hydroxycoronaridine, 3-oxocoronaridine, catharanthine, } \\
\text { voacangine hydroxyindolenine, rupicoline, coronaridinepseudoindoxyl, } \\
\text { tetraphyllicine, olivacine, } 6 \text { N-hydroxyolivacine, 2-N-oxyolivacine, } \\
\text { Nb-demethylvoacamine, voacamidine, tabersonine, 19-epivoacristine, } \\
\text { 3-(2-oxopropyl) coronaridine, 12-methoxy-4-methylvoachalotine, voacristine, } \\
\text { coronaridinehydroxyindolenine, voacristinehydroxyindolenine, vobasine, } \\
\text { voachalotine, voachalotine }\end{array}$ & [24-34] \\
\hline
\end{tabular}

Tabernaemontana coriaceae

Tabernaemontana corymbosa

Tabernaemontana crassa

Tabernaemontana dichotoma

Tabernaemontana dichotoma

Taberpsychine, vincadifformin
[35]

Conoliferine, conodiparine $\mathrm{A}$, conodiparine $\mathrm{C}$, tronoharine, voastrictine, vobatricine, conodiparine E, conodirinine A, conodirinine B

Conoduramine, 19-hydroxyconopharyngine, crassanine, ibogamine, coronaridine, isovoacangine, conopharyngine, apparicine

16,22-dihydro-16-hydroxyapparicine, dichomine, vallesamine, voacamine

16-epi-affinine, coronaridine-hydroxyindolenine, voachalotine,

voacristine-hydroxyindolenine, 12-methoxy-n-methyl-voachalotine, conofoline, conophyllidine, 3S-cyanocoronaridine, 5-hydroxy-6-oxocoronaridine,

Tabernaemontana divaricata

5-oxocoronaridine, 6-oxocoronaridine, ibogamine, voacangine, 3-ethoxyvoacangine, voaharine, voalenine, coronaridine, heyneanine, voacristine, voacamine,

decarbomethoxyvoacamine, 19,20-dihydroervahanine, 19,20-dihydrotabernamine, 19,20-dihydro-ervahanine A, conodurine, tabernaelegantine A

\begin{tabular}{|c|c|c|}
\hline Tabernaemontana elegans & Apparicine, dregamine, vobasine, dregamine, tabernaemontaninol, voacangine & {$[20,55,56]$} \\
\hline Tabernaemontana heterophylla & Voacangine, coronaridine, 19-heyneanine, vobasine, affinisine, olivacine & [57] \\
\hline Tabernaemontana hystrix & $\begin{array}{l}\text { Ibogaine, iboxygaine, voacangine, coronaridine, voacristine, 19-epivoacristine, } \\
\text { iboxygaine, hydroxyindolenine, montanine, vobasine, olivacine, ibogamine, affinine, } \\
\text { hystrixnine, affinisine, Nb-methylaffinisine, coronaridine, 3-oxocoronaridine, } \\
\text { 5-oxocoronaridine, ibogamine-5,6-dione, coronaridinehydroxyindolenine, vobasine, } \\
\text { 12-methoxy-voachalotine }\end{array}$ & {$[58-60]$} \\
\hline Tabernaemontana pachysiphon & Conodurine, 3-hydroxyconopharyngine,16-epiisositsirikine & {$[1,44]$} \\
\hline Tabernaemontana laeta & $\begin{array}{l}\text { Vobasine, affinine, normacusine B, geissoschizol, voacamine, conodurine, vobasine, } \\
\text { affinine, akuammidine, affinisine, geissoschizol, voacamine, conodurine, } \\
\text { coronaridine, conoduramine, voacangine, isovoacristine, Nb-methylvoachalotine, } \\
\text { tabernamine, ibogamine, conopharyngine, voacangine hydroxyindolenine, } \\
\text { voachalotine oxindole, normacusine B, pericyclivine, dehydrovoachalotine, } \\
\text { Nb-methylvoachalotine, olivacine }\end{array}$ & {$[61-65]$} \\
\hline Tabernaemontana rupicola & Rupicoline, montanine & [66] \\
\hline Tabernemontana salzmannii & $\begin{array}{l}\text { Voacangine, isovoacangine, (3S)-hydroxyisovoacangine, coronaridine, } \\
\text { 3-oxo-coronaridine, (19S)-heyneanine, voachalotine, olivacine }\end{array}$ & {$[67]$} \\
\hline Tabernaemontana siphilitica & Isobonafousine & {$[68]$} \\
\hline Tabernaemontana solanifolia & $\begin{array}{c}\text { Voacangine, isovoacangine, coronaridine, heyneanine, isovoacristine, voacangine } \\
\text { hydroxyindolenine, vobasine, voachalotine, } \\
\text { 12-methoxy-Nb-methylvoachalotine, voacamine }\end{array}$ & {$[69]$} \\
\hline Tabernaemontana stapfiana & Ibogamine & {$[35,43,44]$} \\
\hline
\end{tabular}

For centuries, several Tabernaemontana species, such as T. divaricata, T. catharinensis, T. crassa, and T. elegans, have been exploited in traditional and folk medicine for the treatment of illnesses and the prevention of diseases and ailments, such as sore throat, hypertension, abdominal pain, and pulmonary disease [9,20,70-72]. A variety of chemical compounds extracted from many parts of Tabernaemontana species reportedly contain alkaloids, which exhibit biological activities, such as antimicrobial, antioxidant, anti-inflammatory, anticholinesterase, antineurodegenerative, anticancer, antidiabetic, antivenom, larvicidal, antihypertensive, wound healing, analgesic, and many other activities $[2,3,6,9,71,72]$. The 
details of the isolated compounds and respective pharmacological properties of a few Tabernaemontana species are summarized in the following paragraphs.

The findings of Nicola et al. [9] provide scientific support to the frequently used traditional medicinal plant $T$. catharinensis. The outcomes of the study revealed the presence of major alkaloids, such as 16-epi-affinine, coronaridine-hydroxyindolenine, voachalotine, voacristine-hydroxyindolenine, 12-methoxy-n-methyl-voachalotine, and a derivative of voacristine or voacangine (Table 1). It was suggested by Nicola et al. [9] that these chemical constituents exhibited anticholinesterase activity and can be recommended for the future treatment of neurodegenerative disease. According to Mairura [45], a substantial amount of indole alkaloids have been identified and isolated from the stem bark, rootbark, and seeds of T. crassa. Major alkaloids include those of the ibogan class, such as coronaridine, monoand di-methoxy derivatives of isovoacangine, conopharyngine, and the aspidospermatanclass apparicine (Table 1). Mairura [45] explained that the plant is highly toxic, as crude ethanolic extracts were found to be lethal to test subjects. Conversely, the study of Kuete et al. [73] investigated the toxicity of hydro-ethanol stem-bark extracts and the results showed no toxicological activity, thus suggesting a novel source of naturally produced drugs. Ingkaninan et al. [53] investigated the phytochemical properties of the flowers, leaves, stems, and root extracts of T. divaricata. Additionally, four isolated compounds, namely 19,20-dihydrotabernamine, 19,20-dihydro-ervahanine A, conodurine, and tabernaelegantine $\mathrm{A}$, were screened for biological activity. The findings revealed that the extracts and respective compounds displayed high antiacetylcholinesterase activity. Furthermore, studies have shown that isolated compounds from $T$. divaricata, such as conophylline, were effective against in several cell lines [74]. Previous phytochemical research has shown T. elegans to contain several monoterpenoid indole alkaloids of which 24 were previously isolated [56]. The major indole alkaloidal components extracted from the whole plant and root bark of $T$. elegans were vobasine, dregamine, and tabernaemontaninol [6,16,55]. A recent study by Pallant et al. [20] reported the isolation and identification of alkaloids in the root extract of T. elegans. Major components observed were dregamine and voacangine, which exhibited significant antibacterial activity against Gram-positive bacteria and Mycobacterium species.

Despite the variety of biologically active compounds displayed in the above-mentioned species and Table 1, several other Tabernaemontana species, such as T. ventricosa, lack an in-depth chemical and pharmacological investigation. A few studies have observed the bioactivity of T. ventricosa [1,75]. Van Beek et al. [1] reported that the alkaloid akuammicine, belonging to the strychnan class, exhibited opioid activity in opiate receptor studies. The same group investigated the antibacterial, antifungal, and antimalarial activities of $T$. ventricosa extracts; however, no activity was observed in vitro. Mehrbod et al. [75] investigated the effect of $T$. ventricosa plant extracts on the influenza A virus. This investigation supported the study of Van Beek et al. [1], as the results concluded that the leaf extracts of T. ventricosa were ineffective against the influenza A virus. Due to the traditional uses of T. ventricosa being very similar to those of other well-known studied species, little to no studies have been conducted on T. ventricosa, thus it is necessary to evaluate the complete medicinal potential of this species and other Tabernaemontana species to determine its probable pharmacological activities. Considering the several uses of Tabernaemontana species in traditional medicine, many of their proposed biological activities have been confirmed, others invalidated, while countless species remain undefined [2]. Additionally, the improvements in science and medicine have allowed the discovery of new properties of extracts, fractionations, and the identification and isolation of novel compounds [2].

\subsection{Antioxidant Activity}

Antioxidants are identified as molecules or compounds that regulate the process of autoxidation either by intersecting the movement of free radicals or directly constraining their formation [76,77]. Medicinal plants are often recognized for their rich source of antioxidants, which include phenolic acids, phenolic diterpenes, flavonoids, volatile oils, 
carotenoids, and anthocyanidins [77]. These compounds target free radicals by quenching oxygen molecules, breaking antioxidant chains, donating hydrogen molecules, or acting as reducing agents $[76,78]$. Therefore, antioxidants are suggested to decrease oxidative stress, improve immune function, and increase healthy longevity [76-78]. Several factors can alter the antioxidant capacity of a certain species; these include the rate of reaction between the samples and the reactive species and the concentration ratio between the antioxidant and the target [2]. There are multiple methods used to determine the antioxidant activity of plant species; however, various methods may result in variation of the results [79]. Many species within the Tabernaemontana genus have been investigated for their antioxidant activity using different techniques, which include the inhibition and scavenging activity of reactive oxygen species and reactive nitrogen species, reducing capacity, and metal-chelating capacity [2]. The most frequently studied species within the genus is T. catharinensis [9]. Table 2 summarizes the antioxidant properties of Tabernaemontana species. Boligon et al. [80] investigated the crude leaf extracts and fractions of $T$. catharinensis by using the thiobarbituric acid reactive substances technique. Ethyl acetate and n-butanol fractions, yielding a half-maximal inhibitory concentration $\left(\mathrm{IC}_{50}\right)$ of $6.71 \pm 0.19 \mu \mathrm{g} / \mathrm{mL}$ and $26.15 \pm 0.08 \mu \mathrm{g} / \mathrm{mL}$, respectively, displayed optimal results. Furthermore, the same study also assessed the 1,1-Diphenyl-2-picrylhydrazyl (DPPH) inhibition of $T$. catharinensis extracts, which exhibited good results, with an $\mathrm{IC}_{50}$ value of $4.64 \pm 1.25$ to $27.78 \pm 0.93 \mathrm{mg} / \mathrm{mL}$ [80]. Additionally, Nicola et al. [9] examined the antioxidant activity of the alkaloidal fraction in the branch and leaf ethanolic extracts of T. catharinensis. The findings of the study revealed significant antioxidant activity from the alkaloidal fraction, with an $\mathrm{IC}_{50}$ of $37.18 \mu \mathrm{g} / \mathrm{mL}$ [9].

Table 2. Antioxidant activities of extracts and compounds isolated from Tabernaemontana species.

\begin{tabular}{|c|c|c|c|c|}
\hline Species & Part/Exudate & Extract/Compound & Models/Methods & References \\
\hline $\begin{array}{l}\text { Tabernaemontana } \\
\text { alternifolia }\end{array}$ & Root and leaf & $\begin{array}{l}\text { Methanol, chloroform, } \\
\text { dichloromethane, and } \\
\text { dichloroethane }\end{array}$ & $\begin{array}{l}\text { 2,2-Diphenyl-1-picrylhydrazyl } \\
\text { (DPPH) method }\end{array}$ & {$[81-86]$} \\
\hline $\begin{array}{l}\text { Tabernaemontana } \\
\text { catharinensis }\end{array}$ & $\begin{array}{l}\text { Branch, leaf, root, stem, } \\
\text { stem bark, and fruit }\end{array}$ & $\begin{array}{l}\text { Supercritical fluid extraction, } \\
\text { essential oils, ethanol, alkaloidal } \\
\text { fractions, 16-epi-affinine, } \\
\text { voacangine, voacristine hydroxy } \\
\text { indolenine, ethyl acetate, } \\
\text { hydroethanol, and fractions }\end{array}$ & $\begin{array}{l}\text { DPPH method, radical } \\
\text { reduction-in vitro, ferric reducing } \\
\text { antioxidant power (FRAP), 2,2- } \\
\text { azino-bis-(3ethylbenzothiazoline- } \\
\text { 6-sulphonic acid (ABTS), coupled } \\
\text { oxidation of carotene and linoleic } \\
\text { acid assay-Male Wistar } \\
\text { diabetic rats }\end{array}$ & {$[9,10,80,87-92]$} \\
\hline $\begin{array}{l}\text { Tabernaemontana } \\
\text { coronaria }\end{array}$ & Flower & $\begin{array}{l}\text { Petroleum ether, alcohol, } \\
\text { and water }\end{array}$ & $\begin{array}{l}\text { Hydroxyl and superoxide radicals } \\
\text { in vitro, nitric oxide (NO) } \\
\text { scavenging, and lipidperoxidation } \\
\text { inhibition activity }\end{array}$ & {$[93,94]$} \\
\hline $\begin{array}{l}\text { Tabernaemontana } \\
\text { corymbosa }\end{array}$ & Root, stem, and leaf & $\begin{array}{l}\text { Petroleum ether, chloroform, } \\
\text { methanol, and water }\end{array}$ & $\begin{array}{c}\text { DPPH method, metal chelation, } \\
\text { and reducing power } \\
\text { methods-In vitro }\end{array}$ & [95] \\
\hline $\begin{array}{l}\text { Tabernaemontana } \\
\text { divaricata }\end{array}$ & $\begin{array}{l}\text { Leaf, flower, stem, root, } \\
\text { and latex }\end{array}$ & $\begin{array}{l}\text { Methanol, aqueous, ethanol, } \\
\text { petroleum ether, hexane, } \\
\text { chloroform, and ethyl acetate, } \\
\text { ethyl-4-n-octyl benzoate, } \\
\text { ethyl-4-n-decyl benzoate, and } \\
\text { digalactosyldeconate. }\end{array}$ & $\begin{array}{l}\text { FRAP, DPPH method-in vitro, } \\
\text { hydrogen peroxide }\left(\mathrm{H}_{2} \mathrm{O}_{2}\right) \text { free } \\
\text { radicals, reducing power-in vitro, } \\
\text { superoxide anion radical } \\
\text { scavenging, } \mathrm{NO}, \mathrm{ABTS}, \mathrm{H}_{2} \mathrm{O}_{2} \\
\text { scavenging, and } \mathrm{A} \beta_{25-35} \text { peptide, } \\
\text { Novel object recognition test } \\
\text { (NOR), crystal violet staining and } \\
\text { lipid peroxidation }\end{array}$ & {$[82,83,96-105]$} \\
\hline $\begin{array}{l}\text { Tabernaemontana } \\
\text { heyneana }\end{array}$ & $\begin{array}{l}\text { Leaf, stem, bark, and } \\
\text { trunk }\end{array}$ & $\begin{array}{l}\text { Ethanol and sodium } \\
\text { hypochlorite }\end{array}$ & $\begin{array}{l}\text { Total phenolic content and } \\
\text { DPPH method }\end{array}$ & {$[106,107]$} \\
\hline Tabernaemontana recurva & Whole plant & Methanol & Total phenolic content & [108] \\
\hline
\end{tabular}




\subsection{Anti-Inflammatory Activity}

Inflammation is defined as a compound biological process that involves an adamant response of an organism to injury or damage of tissue [109]. The development of inflammation is often induced by microbial infection, chemical injury, cell injury, and death [110]. The consequences of these inducers are primarily indicated by pain, redness, heat, and swelling, which arise due to the deviations in blood flow, capillary permeability, and afferent nerve fibers [111,112]. Subsequently, these changes imitate the restoration of inflamed tissue and constrain additional damage to the organism [109]. Based on the characteristics of inflammation, this composite process is divided into two major types known as acute and chronic inflammation $[72,109,113]$. Acute inflammation occurs almost instantly, or a few hours following injury, and usually displays symptoms of redness, heat, and edema [72]. Whereas, chronic inflammation occurs over an extended interval and is histologically characterized by the occurrence of lymphocytes and macrophages, which subsequently results in the development of fibrosis and necrosis tissue [114]. The standardized protocol for the evaluation of anti-inflammatory activity comprises ex vivo and in vivo experiments [2]. Many Tabernaemontana species have been assessed for anti-inflammatory activity. Table 3 summarizes those anti-inflammatory properties of Tabernaemontana species. Jolly et al. [93], investigated the anti-inflammatory activity of ethanolic flower extract obtained from $T$. divaricata. Mice models were subjected to acute carrageenan and chronic formalin [93]. The results showed significant anti-inflammatory activity in both models at a dose of $100 \mathrm{mg} \mathrm{kg}^{-1}$, in comparison to the standard reference drug diclofenac $\left(25 \mathrm{mg} \mathrm{kg}^{-1}\right)$ [38]. Furthermore, Jain et al. [115] examined the in vivo anti-inflammatory activity of T. divaricata leaves. In this study, hexane fractionations containing a profuse source of flavonoids were tested on male albino mice [115]. The results revealed extensive anti-inflammatory activity, which displayed enhanced results in comparison to the positive drug indomethacin [115].

Table 3. Anti-inflammatory activities of extracts and compounds isolated from Tabernaemontana species.

\begin{tabular}{|c|c|c|c|c|}
\hline Species & Part/Exudate & Extract/Compound & Cell Lines/Models/Methods & References \\
\hline $\begin{array}{l}\text { Tabernaemontana } \\
\text { alternifolia }\end{array}$ & Root & Methanol & $\begin{array}{l}\text { Lethal toxicity annulation } \\
\text { murine models }\end{array}$ & [116] \\
\hline $\begin{array}{l}\text { Tabernaemontana } \\
\text { bufalina }\end{array}$ & Aerial parts & Coronaridine and pandine & $\begin{array}{l}\text { Reduction of lipopolysaccharide } \\
\text { (LPS)—induced NO production }\end{array}$ & [117] \\
\hline $\begin{array}{l}\text { Tabernaemontana } \\
\text { catharinensis }\end{array}$ & Stem bark and leaf, & $\begin{array}{l}\text { Ethanol, ethyl acetate, } \\
\text { dichloromethane, n-butanol, } \\
\text { and hydroethanolic }\end{array}$ & $\begin{array}{l}\text { Carrageenan-induced rat paw } \\
\text { edema in Wistar albino male rat } \\
\text { models, irritant contact } \\
\text { dermatitis models in mice, paw } \\
\text { edema parameters in pain } \\
\text { models involved with TRPA1 } \\
\text { activation and dermatitis models }\end{array}$ & [118-123] \\
\hline $\begin{array}{l}\text { Tabernaemontana } \\
\text { divaricata }\end{array}$ & $\begin{array}{c}\text { Flower, leaf, stem, and } \\
\text { aerial parts }\end{array}$ & $\begin{array}{l}\text { Ethanol, ethyl acetate, aqueous, } \\
\text { methanol and hexane fraction }\end{array}$ & $\begin{array}{l}\text { Carrageenan and formalin } \\
\text { induced-mice models, } \\
\text { reduction of interleukin (IL)- } 6 \\
\text { secretion and tumor necrosis } \\
\text { factor (TNF)- } \alpha \text { production, } \\
\text { Wistar rat models and reduced } \\
\text { croton oil-induced edema in } \\
\text { mice models }\end{array}$ & {$[93,100,102,115,124]$} \\
\hline $\begin{array}{l}\text { Tabernaemontana } \\
\text { pachysiphon }\end{array}$ & Leaf & Tubotaiwine and apparicine & $\begin{array}{l}\text { Mouse abdominal } \\
\text { constriction testing }\end{array}$ & [125] \\
\hline $\begin{array}{l}\text { Tabernaemontana } \\
\text { pandacaqui }\end{array}$ & Stem & Ethanol and alkaloid fraction & $\begin{array}{l}\text { Carrageenan-induced rat paw } \\
\text { edema models }\end{array}$ & [126] \\
\hline $\begin{array}{l}\text { Tabernaemontana } \\
\text { pauciflora }\end{array}$ & Root & $\begin{array}{l}\text { Voacangine, coronaridine and } \\
\text { 3-(2-oxopropyl)-coronaridine }\end{array}$ & Mice and Guinea pig models & [127] \\
\hline
\end{tabular}




\subsection{Antimicrobial Activity}

Antimicrobials are defined as complex compounds that constrain the development of microorganisms at diminutive concentrations [128]. These compounds are often described as secondary metabolites and are regularly produced and extracted from medicinal plants or microorganisms [129]. The efficiency of antimicrobial activity is dependent upon several factors, such as various microbial strains, technique (in vivo or in vitro assay), and type of sample [2]. Studies have reported the evaluation of Tabernaemontana extracts as natural antibiotics [3]. Monoterpenoid indole alkaloids, such as voacamine type and 3-hydroxyiboga, are biologically active compounds and are reportedly used as antimicrobial agents, inhibiting the growth of bacteria, fungi, and parasites [3]. Tables 4-7 summarize the antifungal, antiviral, antibacterial, and antiamoebic properties of Tabernaemontana species.

Table 4. Antifungal activities of extracts and compounds isolated from Tabernaemontana species.

\begin{tabular}{|c|c|c|c|c|}
\hline Species & Part/Exudate & Extract/Compound & Cell Lines/Models/Methods & References \\
\hline $\begin{array}{l}\text { Tabernaemontana } \\
\text { alternifolia }\end{array}$ & Root and leaf & $\begin{array}{l}\text { Methanol, chloroform, } \\
\text { acetone, ethanol, aqueous, } \\
\text { methanol with } 9 \% \text { of water } \\
\text { and } 1 \% \text { of acetic acid }\end{array}$ & $\begin{array}{c}\text { Aspergillus terreus, } \\
\text { Scopulariopsis sp., Aspergillus } \\
\text { niger, Gibberella fujikuroi, } P \text {. } \\
\text { chrysogenum, Candida albicans, } \\
\text { Rhizopus mucor, Aspergillus } \\
\text { parasiticus and Trichoderma } \\
\text { viridians. (T. viride) }\end{array}$ & {$[81,130]$} \\
\hline $\begin{array}{l}\text { Tabernaemontana } \\
\text { angulata }\end{array}$ & Aerial parts & Chloroform and methanol & C. albicans (ATCC 10231) & [131] \\
\hline $\begin{array}{l}\text { Tabernaemontan } \\
\text { catharinensis }\end{array}$ & $\begin{array}{l}\text { Aerial parts, leaf, } \\
\text { root bark, root, and } \\
\text { bark }\end{array}$ & $\begin{array}{l}\text { Methanol, dichloromethane, } \\
\text { n-butanol fractions of } \\
\text { ethanol, ethanol, } 12 \text { methoxy- } \\
\text { Nb-methylvoachalotine }\end{array}$ & $\begin{array}{c}\text { Microsporum canis, } \\
\text { Microsporum gypseum, } \\
\text { Trichophyton mentagrophytes, } \\
\text { Trichophyton rubrum, } \\
\text { Epidermophyton floccosum, C. } \\
\text { albicans, Candida glabrata, } \\
\text { Cryptococcus neoformans, } \\
\text { Saccharomyces cerevisiae, } \\
\text { Aspergillus flavus, Aspergillus } \\
\text { fumigatus and T. rubrum } \\
\text { strains }\end{array}$ & {$[52,132-134]$} \\
\hline $\begin{array}{l}\text { Tabernaemontana } \\
\text { dichotoma }\end{array}$ & $\begin{array}{l}\text { Root bark, stem } \\
\text { bark, leaf, fruit, and } \\
\text { seed }\end{array}$ & Ethanol and methanol & $\begin{array}{c}\text { A. niger (ATCC 16904), C. } \\
\text { albicans (ATCC 10235), A. } \\
\text { niger (MTCC 281), C. albicans } \\
\text { (ATCC 10231), P. chrysogenum } \\
\text { (MTCC 2725), Phanerochaete } \\
\text { chrysosporium (MTCC 787), } \\
\text { and Ralstonia entropha } \\
\text { (MTCC 1255) }\end{array}$ & [135-137] \\
\hline $\begin{array}{l}\text { Tabernaemontana } \\
\text { divaricata }\end{array}$ & Flower and leaf & $\begin{array}{l}\text { Ethanol, methanol and } \\
\text { aqueous }\end{array}$ & $\begin{array}{l}\text { P. chrysogenum, Malassezia } \\
\text { furfur and Poisoned food } \\
\text { technique in vitro }\end{array}$ & {$[54,136,138,139]$} \\
\hline $\begin{array}{l}\text { Tabernaemontana } \\
\text { elegans }\end{array}$ & Root & Ethanol & $\begin{array}{l}\text { C. albicans (ATCC 10231) and } \\
\text { C. albicans (NHLS 255) }\end{array}$ & [140] \\
\hline $\begin{array}{l}\text { Tabernaemontana } \\
\text { pachysiphon }\end{array}$ & Root bark & Ethanol & A. niger and C. albicans & {$[141,142]$} \\
\hline $\begin{array}{l}\text { Tabernaemontana } \\
\text { solanifolia }\end{array}$ & Leaf, bark, and root & Methanol & C. albicans B311 strain & [69] \\
\hline $\begin{array}{l}\text { Tabernaemontana } \\
\text { stapfiana }\end{array}$ & $\begin{array}{l}\text { Leaf, fruit, root, and } \\
\text { stem bark }\end{array}$ & $\begin{array}{l}\text { Methanol fractions-hexane, } \\
\text { dichloromethane, ethyl } \\
\text { acetate and methanol }\end{array}$ & $\begin{array}{l}\text { C. albicans (ATCC 90028), C. } \\
\text { neoformans (ATCC 66031), M. } \\
\text { gypseum (KMR 101), and T. } \\
\text { mentagrophytes (KMR 100) }\end{array}$ & [143] \\
\hline
\end{tabular}


Table 5. Antiviral activities of extracts and compounds isolated from Tabernaemontana species.

\begin{tabular}{|c|c|c|c|c|}
\hline Species & Part/Exudate & Extract/Compound & Cell Lines/Models/Methods & References \\
\hline $\begin{array}{l}\text { Tabernaemontana } \\
\text { catharinensis }\end{array}$ & Stem bark & $\begin{array}{l}\text { Dichloromethane, ethyl } \\
\text { acetate, and n-butanol } \\
\text { fractions of ethanol }\end{array}$ & $\begin{array}{l}\text { Herpes simplex virus type } 1 \\
\text { (HSV-1) }\end{array}$ & [132] \\
\hline $\begin{array}{l}\text { Tabernaemontana } \\
\text { cymosa }\end{array}$ & Bark and seed & $\begin{array}{l}\text { Ethanol, lupeol acetate } \\
\text { and voacangine }\end{array}$ & $\begin{array}{c}\text { Dengue virus strains, } \\
\text { DENV-2/NG, and } \\
\text { DENV-2/16681, in cultured } \\
\text { Vero or U937 cells, and } \\
\text { Chikungunya Virus }\end{array}$ & {$[144,145]$} \\
\hline $\begin{array}{l}\text { Tabernaemontana } \\
\text { elegans }\end{array}$ & Leaf and stem & Ethanol & HSV-1 & [146] \\
\hline $\begin{array}{l}\text { Tabernaemontana } \\
\text { laeta }\end{array}$ & Leaf, stem, and latex & Hydroethanol & $\begin{array}{c}\text { HSV-1, vaccinia virus } \\
\text { Western Reserve } \\
\text { (VACV-WR), and } \\
\text { encephalomyocarditis virus } \\
\text { (EMCV) }\end{array}$ & [147] \\
\hline $\begin{array}{c}\text { Tabernaemontana } \\
\text { pachysiphon }\end{array}$ & Root and stem bark & Ethanol & $\begin{array}{l}\text { HSV-1, poliovirus, and } \\
\text { Semlicki Forest virus }\end{array}$ & [148] \\
\hline $\begin{array}{l}\text { Tabernaemontana } \\
\text { ventricosa }\end{array}$ & Leaf & Methanol & Influenza A virus (IAV) & [75] \\
\hline
\end{tabular}

Table 6. Antibacterial activities of extracts and compounds isolated from Tabernaemontana species.

\begin{tabular}{|c|c|c|c|c|}
\hline Species & Part/Exudate & Extract/Compound & Cell Lines/Models/Methods & References \\
\hline $\begin{array}{l}\text { Tabernaemontana } \\
\text { alternifolia }\end{array}$ & $\begin{array}{l}\text { Stem bark } \\
\text { and root }\end{array}$ & $\begin{array}{l}\text { Aqueous, petroleum ether, } \\
\text { methanol, chloroform, acetone, } \\
\text { ethanol, dichloromethane, } \\
\text { dichloroethane, and ethyl acetate }\end{array}$ & $\begin{array}{c}\text { Methicillin-resistant S. aureus (MRSA), } \\
\text { vancomycin-resistant S. aureus (VRSA), Bacillus } \\
\text { subtilis (ATCC 6633), Staphylococcu aureus (ATCC } \\
\text { 6538P), Staphylococcus epidermidis (ATCC 12228), } \\
\text { Escherichia coli (ATCC 8739), S. aureus (ATCC 43300), } \\
\text { P. aeruginosa (DMH 1), S. aureus (DMH 2-DMH 8 } \\
\text { and 10-DMH 14), E. coli (DMH 9), Bacillus flexus } \\
\text { and Proteus aureus, Salmonella typhi, Klebsiella } \\
\text { pneumoniae, Bacillus cereus, S. aureus (NCIM-2931), } \\
\text { Pseudomonas aeruginosa (NCIM-2200), Proteus } \\
\text { vulgaris (NCIM-2813), E. coli (NCIM-2931), E. coli } \\
\text { (ATCC 8739), and MRSA (ATCC 43300) }\end{array}$ & {$[81,86,106,149]$} \\
\hline $\begin{array}{l}\text { Tabernaemontana } \\
\text { angulata }\end{array}$ & $\begin{array}{l}\text { Aerial parts } \\
\text { and stem }\end{array}$ & $\begin{array}{l}\text { Chloroform, methanol, } \\
\text { dichloromethane/methanol, } \\
\text { and aqueous }\end{array}$ & $\begin{array}{l}\text { P. aeruginosa (ATCC 90270), S. aureus (ATCC 6538), } \\
\text { and C. albicans }\end{array}$ & {$[23,28,131]$} \\
\hline $\begin{array}{l}\text { Tabernaemontana } \\
\text { catharinensis }\end{array}$ & $\begin{array}{l}\text { Thin branch, } \\
\text { leaf root and, } \\
\text { stem bark }\end{array}$ & $\begin{array}{c}\text { Alkaloid fraction, ethanol, } \\
\text { methanol alkaloids, } \\
\text { dichloromethane, n-butanol } \\
\text { fractions and 12-methoxy-Nb- } \\
\text { methylvoachalotine, } \\
\text { Monogagaine and vobparicine }\end{array}$ & $\begin{array}{l}\text { Mycobacterium tuberculosis H37Rv, Mycobacterium } \\
\text { avium, Mycobacterium kansasii, Mycobacterium } \\
\text { malmoense, Mycobacterium fortuitum, Mycobacterium } \\
\text { smegmatis, Micrococcus sp., Enterococcus faecalis, } \\
\text { Proteus mirabilis, S. aureus, Aeromonas sp., E. coli, K. } \\
\text { pneumoniae, P. aeruginosa, B. subtilis (ATCC 6633), S. } \\
\text { aureus (ATCC 25923), S. aureus MR (ATCC 43300), S. } \\
\text { epidermidis (ATCC1220228), E. coli (ATCC 35218), } \\
\text { Enterobacter cloacae (ATCC 202), P. aeruginosa (ATCC } \\
\text { 27853), Streptococcus faecalis (ATCC 29232), K. } \\
\text { pneumoniae (ATCC 700603), Salmonella enteritidis (EB } \\
\text { 1874/88), Shigella flexneri (2EB 7), Acinetobacter } \\
\text { lwoffii strains, T. rubrum, Enterococcus sp., and } \\
\text { Citrobacter }\end{array}$ & $\begin{array}{c}{[1,52,88,132,} \\
150-155]\end{array}$ \\
\hline $\begin{array}{l}\text { Tabernaemontana } \\
\text { citrifolia }\end{array}$ & Not indicated & Voacangine and ibogaine & M. tuberculosis, M. avium, and M. kansasii & [156] \\
\hline
\end{tabular}


Table 6. Cont

\begin{tabular}{|c|c|c|c|c|}
\hline Species & Part/Exudate & Extract/Compound & Cell Lines/Models/Methods & References \\
\hline $\begin{array}{l}\text { Tabernaemontana } \\
\text { coronaria }\end{array}$ & Leaf & Methanol & M. tuberculosis H37Rv (ATCC 2561) & [157] \\
\hline $\begin{array}{l}\text { Tabernaemontana } \\
\text { corymbosa }\end{array}$ & Stem bark & Alkaloid fraction & $\begin{array}{l}\text { B. cereus (ATCC 11778), P. aeruginosa (ATCC 27853), } \\
\text { S. aureus (ATCC 25923), and E. coli (ATCC 35218) }\end{array}$ & [158] \\
\hline $\begin{array}{l}\text { Tabernaemontana } \\
\text { dichotoma }\end{array}$ & $\begin{array}{l}\text { Root bark, stem } \\
\text { bark, stem, bark, } \\
\text { leaf, and fruit }\end{array}$ & $\begin{array}{l}\text { Monogagaine, acid aqueous, } \\
\text { and ethanol }\end{array}$ & $\begin{array}{c}\text { B. subtilis, B. subtilis (ATCC 6633), S. aureus } \\
\text { (ATCC 6538), P. aeruginosa (ATCC 9027), and E. coli } \\
\text { (ATCC 8739) }\end{array}$ & {$[11,52]$} \\
\hline $\begin{array}{l}\text { Tabernaemontana } \\
\text { divaricata }\end{array}$ & $\begin{array}{l}\text { Leaf, bark, petal, } \\
\text { flower, twig, } \\
\text { and root }\end{array}$ & $\begin{array}{l}\text { Ethanol, chloroform, petroleum } \\
\text { ether, diethyl ether, methanol, } \\
\text { aqueous, acetone, alkaloids, } \\
\text { 5-oxocoronaridine, alkaloid } \\
\text { fraction, Dichloromethane, ethyl } \\
\text { acetate, taberdivamines A and B }\end{array}$ & $\begin{array}{c}\text { K. pneumoniae, S. aureus, Staphylococcus } \\
\text { saprophyticus, Streptococcus agalatiae, Streptococcus } \\
\text { pyogenes, E. faecalis, S. typhi, E. coli, Shigella boydii, } \\
\text { Shigella dysenteriae, P. aeruginosa, B. cereus, Klebsiella } \\
\text { sp., Streptococcus uberis, E. coli (ATCC 25922), K. } \\
\text { pneumoniae (ATCC 35657), Salmonella typhimurium } \\
\text { (MTCC 441), S. flexneri (ATCC 29508), S. aureus } \\
\text { (ATCC25923), Aeromonas hydrophila, } \\
\text { S. epidermidis, Gardnerella vaginalis, Streptococcus } \\
\text { agalactiae, Propionibacterium acnes, Corynebacterium } \\
\text { macbinleyi, B. subtilis, S. faecalis, Bacillus megaterium, } \\
\text { P. mirabilis, S. flexneri (BCH 995), S. boydii (8), } \\
\text { Shigella sonnei (NK 840), S. dysenteriae (1), S. } \\
\text { dysenteriae (9), Vibrio cholerae (1023), V. atherin (1341), } \\
\text { V. cholerae (575), V. cholerae (1311), } \\
\text { V. cholerae (756), E. coli (RH 07/12), E. coli (18/9), E. } \\
\text { coli (K88), Enterobacter spp., Streptococcus suis, } \\
\text { Salmonella sp., Corynebacterium diphtheriae(AP596), S. } \\
\text { aureus (ML 267), S. aureus (MTCC 96), S. aureus } \\
\text { (ATCC 6538), B. subtilis (MTCC 441), Bacillus pumilis } \\
\text { (8241) P. aeruginosa (AP585 NLF), K. pneumoniae } \\
\text { strains, Salmonella Paratyphi, Lacto bacillus, P. } \\
\text { vulgaris, and Enterobacter aerogenes }\end{array}$ & $\begin{array}{l}{[48,54,97,100,} \\
136,159-168]\end{array}$ \\
\hline $\begin{array}{l}\text { Tabernaemontana } \\
\text { elegans }\end{array}$ & Root & $\begin{array}{l}\text { Ethanol, hexane, } \\
\text { dichloromethane, and } \\
\text { ethyl acetate }\end{array}$ & $\begin{array}{c}\text { Haemophilus influenzae (ATCC 49217), H. influenzae } \\
\text { (NHLS 609), B. subtilis (ATCC 6633), E. faecalis } \\
\text { (ATCC 29212), S. aureus (ATCC 1200), S. aureus } \\
\text { (ATCC 12600), S. aureus (NHLS 363), S. aureus } \\
\text { (NHLS 284), Streptococcus pneumoniae (ATCC 49619), } \\
\text { S. pneumoniae (NHLS 203), S. pneumoniae (NHLS } \\
\text { 405), M. tuberculosis resistant (MRC 3366), M. } \\
\text { tuberculosis H37RV (ATCC 25177), M. smegmatis } \\
\text { (ATCC 14468), E. coli (ATCC 35218), K. pneumoniae } \\
\text { (ATCC 13883), and P. aeruginosa (ATCC 9027), M. } \\
\text { tuberculosis H37Rv }\end{array}$ & {$[20,140,169]$} \\
\hline $\begin{array}{l}\text { Tabernaemontana } \\
\text { heterophylla }\end{array}$ & Stem & Dichloromethane & M. tuberculosis & [170] \\
\hline $\begin{array}{l}\text { Tabernaemontana } \\
\text { pachysiphon }\end{array}$ & $\begin{array}{l}\text { Leaf, root, and } \\
\text { stem bark }\end{array}$ & $\begin{array}{c}\text { Ethanol, Ibogaine, } 12 \\
\text { methoxy-ibogamine, } \\
\text { 10-methoxyibogamine and } \\
\text { 3-R/S-hydroxy-conopharyngine }\end{array}$ & $\begin{array}{c}\text { S. aureus, E. coli, B. subtilis, Agrobacterium } \\
\text { tumefaciens, B. subtilis (ATCC 6633), S. aureus (ATCC } \\
\text { 6538), P. aeruginosa (ATCC 9027), and E. coli } \\
\text { (ATCC 8739) }\end{array}$ & {$[1,142,171]$} \\
\hline $\begin{array}{l}\text { Tabernaemontana } \\
\text { solanifolia }\end{array}$ & $\begin{array}{l}\text { Leaf, bark, and } \\
\text { root }\end{array}$ & $\begin{array}{c}\text { Voacangine, isovoacangine, } \\
\text { coronaridine, heyneanine, } \\
\text { isovoacristine, voacangine } \\
\text { hydroxyindolenine, vobasine, } \\
\text { voachalotine, 12-methoxy- } \mathrm{Nb} \text { - } \\
\text { methylvoachalotine } \\
\text { and voacamine }\end{array}$ & C. albicans B311 & [69] \\
\hline $\begin{array}{l}\text { Tabernaemontana } \\
\text { stapfiana }\end{array}$ & Root and stem & Methanol & S. aureus, MDRS, E. faecalis, B. subtilis, and S. typhi & [172] \\
\hline
\end{tabular}


Table 7. Antiamoebic activities of extracts and compounds isolated from Tabernaemontana species.

\begin{tabular}{|c|c|c|c|c|}
\hline Species & Part/Exudate & Extract & Cell Lines/Models/Methods & References \\
\hline Tabernaemontanaaurantiaca & Leaf and twig & Ethanol & Entamoebahistolytica & [155] \\
\hline Tabernaemontanachippii & Leaf, root bark, and stem bark & Ethanol & E. histolytica & [155] \\
\hline Tabernaemontanacontorta & Leaf and twig & Ethanol & E. histolytica & [155] \\
\hline Tabernaemontanacrassa & Stem bark & Ethanol & E. histolytica & [155] \\
\hline Tabernaemontanadichotoma & Leaf & Ethanol & E. histolytica & [155] \\
\hline Tabernaemontana glandulosa & Leaf and stem bark & Ethanol & E. histolytica & [155] \\
\hline Tabernaemontanaheterophylla & Leaf and twig & Ethanol & E. histolytica & [155] \\
\hline Tabernaemontanalongiflora & Leaf and twig & Ethanol & E. histolytica & [155] \\
\hline Tabernaemontanaorientalis & Leaf and twig & Ethanol & E. histolytica & [155] \\
\hline Tabernaemontanapachysiphon & Root bark and stem bark & Ethanol & E. histolytica & {$[155,173]$} \\
\hline Tabernaemontanapenduliflora & Stem bark & Ethanol & E. histolytica & {$[165]$} \\
\hline Tabernaemontanapsorocarpa & Leaf & Ethanol & E. histolytica & [165] \\
\hline Tabernaemontanaundulata & Stem bark & Ethanol & E. histolytica & [165] \\
\hline Tabernaemontanaventricosa & Leaf and stem bark & Ethanol & E. histolytica & [165] \\
\hline Tabernaemontana species & Root & Not indicated & E. histolytica & [174] \\
\hline
\end{tabular}

\subsubsection{Antifungal Activity}

Singh et al. [54] investigated the antifungal activity of a biologically active compound from T. divaricata. A major compound from the Tabernaemontana genus, coronaridine (Table 1), was identified and isolated from the ethanolic extract of T. divaricata [54]. In the study, coronaridine displayed weak antifungal activity against Penicillium chrysogenum, comparable with nystatin [minimum inhibitory concentration (MIC) $9.8-14.0 \mathrm{mg} / \mathrm{mL}$ ] [54]. Conversely, Boligon et al. [132] investigated the dichloromethane and n-butanol fractions of ethanolic leaf extracts from T. catharinensis. The dichloromethane fraction showed significant activity against the fungal strains C. albicans, C. glabrata, C. neoformans, S. cerevisiae, A. flavus, and A. fumigatus, with MIC ranging from 31.25 to $1000 \mathrm{mg} / \mathrm{mL}$ [132].

\subsubsection{Antiviral Activity}

Boligon et al. [132] evaluated the dichloromethane, ethyl acetate, and n-butanol fractions from the ethanolic extracts of T. catharinensis. The extracts and fractions displayed substantial antiviral activity on herpes simplex virus type 1 (HSV-1) in contrast to acyclovir ( $\mathrm{IC}_{50} 1.5 \mathrm{mg} / \mathrm{mL}$ ) [132]. Furthermore, significant antiviral activity was observed from the dichloromethane and ethyl acetate fractions. The dichloromethane and ethyl acetate fractions of the bark-stem fractions showed $\mathrm{IC}_{50}$ values of 2.62 and $2.88 \mu \mathrm{g} / \mathrm{mL}$, respectively, whereas the fractions of the leaves showed $\mathrm{IC}_{50}$ values of 0.6 and $2.21 \mu \mathrm{g} / \mathrm{mL}$, respectively [132]. It is suggested that biologically active compounds, such as steroids, terpenoids, and phenolics, found in the dichloromethane, ethyl acetate, and n-butanol fractions are accountable for the antiviral activity [2,132].

\subsubsection{Antibacterial Activity}

Over the past 50 years, extensive research has been conducted about the advancements in antibacterial medicines [175]. Moreover, due to the reoccurrence of multidrug-resistant bacteria, there is an excessive necessity for the development of novel and innovative antibacterial agents against those displaying multidrug resistance $[175,176]$. Approximately $25 \%$ of modern medication has been established on the core basis of plant-related compounds [177]. Thus, the active screening of medicinal plants is imperative for the discovery of new antibacterial compounds [178]. The indole alkaloids of Tabernaemontana exhibit a wide range of pharmacological activities, including antibacterial activity against Grampositive and Gram-negative bacteria [133]. Gindri et al. [150] investigated the antibacterial activity of ethanolic extract and its fractions from the leaves of T. catharinensis. The extracts and fractions were tested against multiple bacterial strains, such as S. aureus, Aeromonas sp., Micrococcus sp., P. mirabilis, E. coli, K. pneumoniae, E. faecalis, and P. aeruginosa, which were comparable against the antibiotics ampicillin (MIC $=8.0 \mathrm{mg} / \mathrm{mL}$ ), cefoperazone $(\mathrm{MIC}=16.0 \mathrm{mg} / \mathrm{mL})$, and imipenem $(\mathrm{MIC}=0.06 \mathrm{mg} / \mathrm{mL})$. The findings showed positive 
results against Micrococcus sp., P. mirabilis, and P. aeruginosa (MIC values of 31.3, 62.5, and $62.5 \mathrm{mg} / \mathrm{mL}$, respectively) [150].

\subsubsection{Antiamoebic Activity}

Parasitic infections are regarded as one of the leading contributors to human health problems and are often distributed via contaminated food and water sources [179]. Amoebiasis is a lethal disease that arises from the ingestion of pathogenic microorganisms and occurs predominantly in tropical areas, including China, Mexico, the Eastern portion of South America, South-East and West Africa, Asia, and the Indian subcontinent [180,181]. The protozoan parasite E. histolytica is dominant in these regions and affects approximately $12 \%$ of the world's population, whilst being responsible for copious mortality rates, ranging from 40,000 to 110,000 per year $[180,182]$. Since there is no vaccine against $E$. histolytica, metronidazole (MNZ) is regularly used to treat infection against amoebiasis; however, there are serious consequences of the drug, such as amoebic resistance and several side effects, including impaired physical and mental development [183]. Due to the severe side effects of MNZ, many infected people have opted for a more natural approach using traditional medicine [180]. Several Tabernaemontana species are often used in various parts of the world for their antimicrobial, antiparasitic, and antiamoebic action. Van Beek et al. [1] investigated a variety of Tabernaemontana species to establish their antiamoebic activity. In the study, approximately 15 Tabernaemontana species were tested against the protozoan E. histolytica. The study exhibited adequate results, as four extracts from three species showed promising activity below $0.5 \mathrm{mg} / \mathrm{mL}$ against the parasite protozoan E. histolytica [1]. Additionally, Uwumarongie et al. [141] evaluated the antiamoebic activity of T. pachysiphon root and stem bark extracts. The findings of their study showed relatively high antiamoebic activity against E. histolytica [141].

\subsection{Anticancer and Cytotoxicity}

The irrepressible division of cells habitually leads to the formation of cell masses, which are frequently termed as 'growths' or 'tumors' [184]. These masses are classified as malignant (cancerous) or benign (noncancerous) and are often influenced by several characteristics, such as an irregular diet, genetic factors, and ecological aspects $[185,186]$. These negative influences give rise to an amplified rate of cancer, since approximately 18.1 million people are expected to be diagnosed with cancer [187-189]. However, with the consistent applications of effective cancer treatments, such as radiotherapy, surgery, immunotherapy, and chemotherapy, these values may subside $[190,191]$. However, among these treatments, chemotherapy remains challenging due to the occurrence of multidrug resistance (MDR), which is defined as the resistance of tumors to chemotherapeutic agents [192]. Considering the above, the constant discovery of anticancer agents using medicinal plants has displayed minimal side effects and act as modulators of MDR. Thus, recently, several medicinal plants, especially within the genus Tabernaemontana, have been screened to evaluate their potential effect on the growth and development of cancerous cells [2].

The study conducted by Pereira et al. [33] investigated the isolation, structure, and chemical constituents present in the root bark of T. catharinensis. Twenty-seven compounds were detected in the ethanol and $n$-butanol extracts, however, only 12 compounds were identified. Approximately three compounds, namely, ibogamine, 3-oxo-coronaridine, and 12-methoxy-4-methylvoachalotine (MMV) (Table 1), showed substantial cytotoxicity against SKBR-3 breast adenocarcinoma and C-8161 human melanoma tumor cell lines [33]. Thind et al. [193] examined the cytotoxic properties of T. divaricata. In the study, various leaf extracts prepared in a range of solvents (chloroform, methanol, ethyl acetate, and hexane) were tested against the following cell lines: HCT-15 (colon), HT-29 (colon), 502,713 (colon), MCF-7 (breast), and PC-3 (prostate) [193]. Ethyl acetate extract was the most promising as it displayed significant cytotoxic activity against the colon cell line (502713) with a low dose of $10 \mu \mathrm{g} / \mathrm{mL}$ [193]. Additionally, the chloroform extracts also showed considerable cytotoxicity against three colon cell lines with a slightly higher dosage of $30 \mu \mathrm{g} / \mathrm{mL}$ [193]. 
In another study, Rumzhum et al. [96] screened the leaf extracts of T. divaricata using a brine shrimp bioassay. The results of the study revealed possible cytotoxicity $\left(\mathrm{LC}_{50}=1 \mu \mathrm{g} / \mathrm{mL}\right)$ in comparison to the positive control, vincristine sulphate $\left(\mathrm{LC}_{50}=0.3 \mu \mathrm{g} / \mathrm{mL}\right)$ [95]. Figueiredo et al. [67] reported the cytotoxicity of T. salzmannii root and leaf extracts on human leukemia cells (THP-1). In this study, nine alkaloids were isolated; however, only two alkaloids, isovoacangine and voacangine (Table 1), displayed extensive cancer cell death, with an $\mathrm{IC}_{50}$ of 52.11 and $61.40 \mu \mathrm{M}$, respectively [67]. The above-isolated compounds from various Tabernaemontana species are frequently used to treat a range of cancer types, such as breast, germ and renal, leukemia, lung, testicular, ovarian, and colon cancer [17,194-198].

Recently, Rosales et al. [189] also evaluated the anticancer properties of indole alkaloids of T. catharinensis. In the study, six compounds were identified, namely, 16-epiaffinine, 12-methoxy- $n$-methyl-voachalotine, affinisine, voachalotine, coronaridinehydroxyindoline, and ibogamine (Table 1) [189]. The isolated indole alkaloids were tested in vitro against several cell lines, including tumor cells A375 (melanoma cell line) and A549 (adenocarcinomic human alveolar basal epithelial cells), and non-tumor Vero cells (African green monkey kidney epithelial cells) [189]. In vitro toxicity showed the fractionation containing affinisine demonstrated toxicity against $\mathrm{A} 375$, with an $\mathrm{IC}_{50}$ of $11.73 \mu \mathrm{g} / \mathrm{mL}$, and may be a chemotherapeutic agent for A375 melanoma cells [189]. Table 8 summarizes the anticancer properties of Tabernaemontana species.

Table 8. Anticancer activities of extracts and compounds isolated from Tabernaemontana species.

\begin{tabular}{|c|c|c|c|c|}
\hline Species & Part/Exudate & Extract/Compound & Cell Lines/Models/Methods & References \\
\hline $\begin{array}{c}\text { Tabernaemontana } \\
\text { angulata }\end{array}$ & Stem & Chloroform and methanol & $\begin{array}{l}\text { Human breast adenocarcinoma (MCF-7), } \\
\text { human prostate cancer (PC-3), human } \\
\text { lung cancer (NCI-H460), human colon } \\
\text { cancer (KM-12), human glioblastoma } \\
\text { (SF-268), and myeloma (RPMI-8226) }\end{array}$ & [23] \\
\hline $\begin{array}{c}\text { Tabernaemontana } \\
\text { alternifolia }\end{array}$ & $\begin{array}{l}\text { Stem bark } \\
\text { and leaf }\end{array}$ & Aqueous, hexane, ethyl acetate, and methanol & $\begin{array}{c}\text { Vero cell line, human gastric carcinoma } \\
\text { (A-549, MCF-7, AGS), human colon } \\
\text { adenocarcinoma (COLO } 320 \text { DM and } \\
\text { Vero cell lines) }\end{array}$ & {$[84,149]$} \\
\hline $\begin{array}{c}\text { Tabernaemontana } \\
\text { bovina }\end{array}$ & Aerial parts & Taberdivarine $\mathrm{C}-\mathrm{F}$ & $\begin{array}{l}\text { Human cervical carcinoma (HeLa), } \\
\text { human breast adenocarcinoma (MCF-7), } \\
\text { and colon carcinoma (SW480) }\end{array}$ & [199] \\
\hline $\begin{array}{l}\text { Tabernaemontana } \\
\text { bufalina }\end{array}$ & Aerial parts & $\begin{array}{c}\text { 3'-(2-oxopropyl)- } 19,20 \text { dihydro-tabernamine, } 3^{\prime}-(2 \\
\text { oxopropyl) ervahanine } \mathrm{B}, 19,20 \text {-dihydrovobparicine, } \\
\text { ibogamine, coronaridine, voacangine, } \\
\text { hainanervatasine, 3-(2-oxopropyl) coronaridine, } \\
\text { 3,3'-(oxopropyl) dicoronaridine, isotabernamine, } \\
\text { taberdivarines C, taberdivarine } \mathrm{D} \text {, tabernaelegantine } \\
\text { B, tabernaelegantinine } \mathrm{B}, 19,20 \text {-dihydrotabernamine } \\
\text { A, taberdivarine E, ervadivaricatine } \mathrm{B} \text {, taberdivarine } \\
\text { F tabernaecorymbosine A, tabernaelegantine C, } \\
\text { tabernaelegantine A, and } \\
\text { 19-(2-oxopropyl)-conoduine }\end{array}$ & $\begin{array}{l}\text { Small cell lung carcinoma (A-549), } \\
\text { human breast adenocarcinoma (MCF-7) }\end{array}$ & [200] \\
\hline $\begin{array}{l}\text { Tabernaemontana } \\
\text { calcarea }\end{array}$ & Whole plant & $\begin{array}{l}\text { Voacristine, isovoacristine, 19-epi-voacristine, } \\
\text { hydroxytabernanthine,11-hydroxycoronaridine, } \\
\text { 19-epi-heyneanine, 3(R/S)-19-epi-3-oxovoacristine, } \\
\text { hydroxyindolenine, 10-methoxyibogamine } \\
\text { (ibogaine), and 11-methoxyibogamine }\end{array}$ & Ovarian cancer (A2780) & [201] \\
\hline $\begin{array}{l}\text { Tabernaemontana } \\
\text { catharinensis }\end{array}$ & $\begin{array}{l}\text { Leaf, seed, root, } \\
\text { bark, and stem }\end{array}$ & $\begin{array}{l}\text { Coronaridine, tabersonine, olivacine, } \\
\text { coronaridine-hydroxyindolenine, catharinensine, } \\
\text { decarbomethoxyvoacamine and tabernamine, } \\
\text { aqueous, ethanol, and alkaloid fraction }\end{array}$ & $\begin{array}{l}\text { Ehrlich's carcinoma, sarcoma 180, human } \\
\text { breast carcinoma (SK-BR-3), melanoma } \\
\text { tumor cells (SK-BR-3 and C-8161), } \\
\text { laryngeal carcinoma (Hep-2 and normal } 3 \\
\text { T3 cell lines), human melanoma cell lines } \\
\text { (A375, WM1366, SK-MEL-28)and a } \\
\text { normal skin cell line (CCD-1059Sk), } \\
\text { adenocarcinomic human alveolar basal } \\
\text { epithelial cells (A549), Vero cells (African } \\
\text { green monkey kidney epithelial cells) }\end{array}$ & $\begin{array}{l}{[33,69,118,189} \\
202-205]\end{array}$ \\
\hline
\end{tabular}


Table 8. Cont.

\begin{tabular}{|c|c|c|c|c|}
\hline Species & Part/Exudate & Extract/Compound & Cell Lines/Models/Methods & References \\
\hline $\begin{array}{c}\text { Tabernaemontana } \\
\text { contorta }\end{array}$ & Root & $\begin{array}{l}\text { Contortarine A, 16-epi-pleiomutinine and } \\
\text { N4-chloromethyl-pleiomutinine }\end{array}$ & $\begin{array}{c}\text { Quinone reductase induction }(\mathrm{QR}) \text { and } \\
\text { NF-kB inhibition assay }\end{array}$ & [206] \\
\hline $\begin{array}{l}\text { Tabernaemontana } \\
\text { corymbosa }\end{array}$ & $\begin{array}{l}\text { Stem bark, leaf, } \\
\text { and twig }\end{array}$ & $\begin{array}{c}\text { Alkaloid fraction, jerantinine A, jerantinine C, } \\
\text { jerantinine B, jerantinine B acetate, jerantinine D, } \\
\text { jerantinine E, jerantinine F, conodiparine A, } \\
\text { oxoconodiparine A, conodiparine B, } \\
\text { oxoconodiparineB, vobasidine A, vobasidine B, } \\
\text { vobasidine C, vobasidine D, } \\
\text { taipinisinetabernaemontanine, dreagamine, vobasine, } \\
\text { 16-epivobasine, vobasenal, 16-epivobasenal and } \\
\text { vincristine, } \\
\text { 16-decarbomethoxy-voacaminepseudoindoxyl, } \\
\text { conolutinine, lirofoline A, conoliferine, conomicidine } \\
\text { A, conomicidineB, ibogamine, ibogaine, } \\
\text { ibogaine-7-hydroxyindolenine, iboxygaine, } \\
\text { iboluteine, coronaridine, heyneanine, } \\
\text { 19-epi-heyneanine, 7(R)-geissoschizol oxindole, } \\
\text { 7(S)-geissoschizol oxindole, } \\
\text { 16(R),7(R)-19,20-eisositsirikine oxindole, affinisine, } \\
\text { voachalotine, norfluorocurarine, antirhine, } \\
\text { velbanamine, 20(S) hydroxy-1,2 } \\
\text { dehydro-pseudo-aspi-dospermidine, tabercorines } \\
\text { A-C, acetyl-tabernaecorymbosine A, tabernaricatine } \\
\text { A, tabernaricatine B, tabernaricatine D, } \\
\text { 16-decarbomethoxyvoacamine, conodurine and } \\
\text { tabernaecorymbosine, taburnaemines A-I, } \\
\text { tabernaecorymbosine A, tabernaricatineC, } \\
\text { tabernaricatine D, } \\
\text { 16'-decarbo-methoxytabernaecorymbosine, } \\
\text { tabercorymines, and conofolidine }\end{array}$ & $\begin{array}{c} \\
\text { Human non-small lung carcinoma } \\
\text { (A549), human cervical carcinoma } \\
\text { (C33A), human oral epidermoid } \\
\text { carcinoma (vincristine resistant KB, } \\
\text { vincristine-sensitive (KB/S), and } \\
\text { vincristine-resistant cells KB/VJ300), } \\
\text { human } \\
\text { colon colorectal (HCT-116 cells, HT-29), } \\
\text { human breast adenocarcinoma } \\
\text { (MDA-MB-231, MCF-7), human breast } \\
\text { cancer (MDA-468), human hepatoma } \\
\text { (Hep-G2 and SMMC-7721) cells, human } \\
\text { leukemia (HL-60), hepatocarcinoma cell } \\
\text { line (SMMC-7721), lung and colon } \\
\text { carcinoma (SW480), human carcinoma } \\
\text { (KB, and P-glycoprotein over-expressing } \\
\text { multi-drug resistant KB cells) and human } \\
\text { carcinoma (KB, KB-VIN cells) }\end{array}$ & {$[158,207-218]$} \\
\hline $\begin{array}{l}\text { Tabernaemontana } \\
\text { divaricata }\end{array}$ & $\begin{array}{l}\text { Leaf, root, stem, } \\
\text { flower, stem bark } \\
\text { aerial parts and } \\
\text { whole plant }\end{array}$ & $\begin{array}{l}\text { Chloroform, petroleum ether, methanol, ethylacetate, } \\
\text { hexane, ethanol, hydroalcohol, acetone, aqueous, } \\
\text { dichloromethane, chloroform-5-oxocoronaridine, } \\
\text { 3-oxocoronaridine, coronaridine, ibogamine, } \\
\text { tabernaemontamine, vobasine, voacamine, } \\
\text { tabernaricatines A-F, bisindole alkaloids, } \\
\text { 16-decarbo-methoxyvoacamine, } \\
\text { tabernaecorymbosine A, isovoacangine, heyneanine, } \\
\text { voacangine, 19acetonyliso-voacangine, vincadiffine, } \\
\text { difforlemeine, voaphylline, hecubine, voacangine } \\
\text { hydroxyindolenine, voacryptine, 19S-heyneanine, } \\
\text { 19S-voacangarine, } \\
\text { lo-methoxyeglandine-noxidelo-hydroxycoronaridine, } \\
\text { heyneatine, O-acetyl vallesamine, pericalline, } \\
\text { dihydrocondylocarpine, camptothecin, } \\
\text { 9-methoxycamptothecin, conoduramine, and } \\
\text { coronaridinehydroxyindolenine }\end{array}$ & $\begin{array}{l}\text { Human colon carcinoma (HCT-15, HT-29, } \\
\text { and 502713), human breast } \\
\text { adenocarcinoma (MCF-7), human } \\
\text { prostate cancer (PC-3), leukemia (HP-1), } \\
\text { brine shrimp lethality, lung carcinoma } \\
\text { large cell (COR-L23), laryngeal carcinoma } \\
\text { (Hep-2), Vero cells, sarcoma 180, cloned } \\
\text { Chinese hamster lung fibroblast (V79 } \\
\text { cells), human colon cancer (HT-29), } \\
\text { human small cell lung carcinoma (A-549), } \\
\text { human hepatic cancer (HepG-2), human } \\
\text { and rat normal skeletal muscle cell } \\
\text { cultures (L6), renal cell carcinoma in } \\
\text { Wistar rats, human myeloid leukemia } \\
\text { (HL-60), hepatocellular carcinoma } \\
\text { (SMMC-7721), colon cancer (SW480), } \\
\text { human breast cancer (BC1), human oral } \\
\text { epidermoid carcinoma (KB), and KB } \\
\text { drug-resistant strain (KB-V1), human } \\
\text { prostate cancer (LNCaP), human lung } \\
\text { cancer (Lu1), murine, lymphocytic } \\
\text { leukemia (P388), human glioma (U373), } \\
\text { human epidermoid carcinoma (A431), } \\
\text { human colon cancer (Col2), human } \\
\text { fibrosarcoma (HT), human melanoma } \\
\text { (Mel2), hormone-dependent breast cancer } \\
\text { (ZR-75-1), K13-V1 cells, and human } \\
\text { leukemia (MOLT4) }\end{array}$ & $\begin{array}{l}{[54,96,160,193,} \\
219-229]\end{array}$ \\
\hline $\begin{array}{c}\text { Tabernaemontana } \\
\text { elegans }\end{array}$ & $\begin{array}{l}\text { Whole plant } \\
\text { and root }\end{array}$ & $\begin{array}{c}\text { Ethanol, ethyl acetate, indole alkaloids, } \\
\text { tabernaelegantinine B, tabernaelegantine C, } \\
\text { dregamine, eleganine A, tabernine A-C, } \\
\text { 16-epi-dregamine, and monomeric indole } \\
\text { bisindole alkaloids }\end{array}$ & $\begin{array}{l}\text { Human macrophages (THP-1 cells), cell } \\
\text { viability screening (trypan blue dye } \\
\text { exclusion assay), human hepatoma } \\
\text { (HuH-7, HCT-116, and SW620 cells), } \\
\text { human cervical epithelial carcinoma } \\
\text { (HeLa), African green monkey kidney } \\
\text { cells (Vero), and human embryonic } \\
\text { kidney (HEK-293), }\end{array}$ & {$[169,230-232]$} \\
\hline $\begin{array}{c}\text { Tabernaemontana } \\
\text { hystrix }\end{array}$ & Root bark & Voacamine & $\begin{array}{c}\text { Lymphoblastoid (CEM-WT), } \\
\text { osteosarcoma (U-2 OS-WT), and } \\
\text { drug-resistant cell lines (CEM-R and } \\
\text { U-2 OS-R) }\end{array}$ & [233] \\
\hline $\begin{array}{l}\text { Tabernaemontana } \\
\text { laeta }\end{array}$ & Stem bark & Ethyl acetate & Human carcinoma (KB cells) & {$[64]$} \\
\hline
\end{tabular}


Table 8. Cont.

\begin{tabular}{|c|c|c|c|c|}
\hline Species & Part/Exudate & Extract/Compound & Cell Lines/Models/Methods & References \\
\hline $\begin{array}{c}\text { Tabernaemontana } \\
\text { pandacaqui }\end{array}$ & Leaf & Ethanol & $\begin{array}{l}\text { Human primary renal cell carcinoma } \\
\text { (786-0), colon adenocarcinoma grade II } \\
\text { (HT-29), ovarian carcinoma (OVCAR-3), } \\
\text { melanoma (SK-MeI-28), glioblastoma } \\
\text { (SNB-19), human breast adenocarcinoma } \\
\text { (MCF-7), human prostate cancer (PC-3), } \\
\text { and small cell lung carcinoma (A549) }\end{array}$ & [234] \\
\hline $\begin{array}{l}\text { Tabernaemontana } \\
\text { solanifolia, }\end{array}$ & $\begin{array}{l}\text { Leaf, bark, } \\
\text { and root }\end{array}$ & 12-methoxy-Nb-methyl-voachalotine & Leukemia (3PS31) & [69] \\
\hline $\begin{array}{l}\text { Tabernaemontana } \\
\text { salzmannii, }\end{array}$ & Root bark & Voacangine & Monocytic leukemia (THP-1) & [67] \\
\hline
\end{tabular}

\subsection{Acetylcholinesterase Activity}

Alzheimer's disease (AD) is defined as an advanced chronic and aggressive neurodegenerative disease, which is habitually accompanied by the severe disturbance of multiple cortical functions, including memory impairment, judgment, orientation, understanding, language learning capacity, and personality changes [235-237]. Clinically, this cognitive disorder is often characterized by the occurrence of several amyloidal beta-peptide plaques, neurofibrillary tangles, atrophy of basal forebrain cholinergic neurons, oxidative stress, and reduced neurotransmitter levels $[9,238,239]$. According to Adewusi and Steenkamp [240], $\mathrm{AD}$ is amongst the leading disorders worldwide as it is liable for approximately $50-60 \%$ of dementia in elders. Moreover, a dramatic incline, possibly affecting $7-10 \%$ of individuals over 65 and $40 \%$ of persons over 80 years, is anticipated within the next 50 years, without the intervention of rehabilitation $[235,240,241]$. Popular methods for the treatment of AD are often based on the cholinergic hypothesis, which suggests that the impairment of memory is directly related to a reduction in the function of cholinergic in the brain [241]. Thus, several approaches regarding the enhancement of acetylcholine levels using acetylcholinesterase (AChE) inhibitors are frequently investigated $[239,241,242]$. Currently, approved AChE inhibitors include tacrine, donepezil, rivastigmine, and galanthamine [238,241,242]. However, despite the beneficial effects on cognitive functioning, these inhibitors have displayed undesirable side effects, such as gastrointestinal issues, nausea, vomiting, and reduced bioavailability $[243,244]$. Considering the latter, the discovery of alternative natural AChE inhibitors displaying minimal side effects is essential $[238,239,244]$. Therapeutic plants have been investigated for their complex compounds that contain natural and innovative AChE inhibitors [241,242]. Several Tabernaemontana species have been recognized and investigated for their monoterpene indole alkaloids, which have demonstrated AChE inhibitory activity [245]. Ingkaninan et al. [241] investigated the AChE inhibitory activity of methanolic extracts of T. divaricata. In the study, extracts $(0.1 \mathrm{mg} / \mathrm{mL})$ were tested in vivo using rats as test models [241]. The results were promising as approximately $90 \%$ of $\mathrm{AChE}$ activity was observed. Furthermore, most recently, Athipornchai et al. [245] investigated the AChE inhibitory activity of the methanol, n-hexane, and ethyl acetate extracts of T. pandacaqui flowers. The results revealed that the ethyl acetate extract displayed the strongest AChE inhibitory activity, with inhibition of $35.4 \%$ at $5 \mathrm{mg} / \mathrm{mL}$ [245]. Considering the latter, prior and recent studies have shown the potential of plant AChE inhibitors, which should be further investigated. Table 9 summarizes the acetylcholinesterase activities of Tabernaemontana species. 
Table 9. Antiacetylcholinesterase activities of extracts and compounds isolated from Tabernaemontana species.

\begin{tabular}{|c|c|c|c|c|}
\hline Species & Plant Organ/Exudate & Extract/Compound & Methods & References \\
\hline $\begin{array}{c}\text { Tabernaemontana } \\
\text { amygdalifolia }\end{array}$ & Latex & Ethanol and methanol & Ellman's method & [246] \\
\hline $\begin{array}{c}\text { Tabernaemontana } \\
\text { australis }\end{array}$ & Stem and stalk & Ethanol & Ellman's method & [242] \\
\hline $\begin{array}{c}\text { Tabernaemontana } \\
\text { divaricata }\end{array}$ & $\begin{array}{l}\text { Leaf, flower, root, stem, } \\
\text { and latex }\end{array}$ & $\begin{array}{l}\text { Methanol, ethanol, phosphate } \\
\text { buffer, petroleum ether, } \\
\text { dihydrotabernamine, } \\
\text { 19,20-dihydro-ervahanine A, } \\
\text { conodurine, tabernaelegantine A, } \\
\text { Taberhanine, voafinine, } \\
\text { N-methylvoafinine, voafinidine, } \\
\text { voalenine, conophyllinine, } \\
\text { conophylline, and conofoline, }\end{array}$ & Ellman's method & $\begin{array}{c}{[51,53,193,237,} \\
238,241,247,248]\end{array}$ \\
\hline Tabernaemontana iboga & Root bark & Ibogaine and physostigmine & Ellman's method & [249] \\
\hline Tabernaemontanalaeta & Stalk and stem & Ethanol & Ellman's method & {$[61]$} \\
\hline $\begin{array}{c}\text { Tabernaemontana } \\
\text { pandacaqui }\end{array}$ & Flower & Methanol & Ellman's method & [245] \\
\hline
\end{tabular}

\subsection{Other Activities}

Khan [98] investigated the gastrointestinal effects of the methanol extract from $T$. divaricata flowers. In the study, a rat pyloric ligation-induced gastric ulceration model was used to evaluate the potential effects, along with the standard drug omeprazole $(8.0 \mathrm{mg} / \mathrm{kg})$ [98]. It was revealed that the extract reduced the amount of gastric juice, free and total acidities, ulcer index, and $\mathrm{pH}$ of gastric acid produced [98]. The standard drug, omeprazole showed a percentage protection of $89.8 \%$, and the extract $79.5 \%$ [98]. In another report, Khan et al. [250] further examined the methanol extract from the flowers of T. divaricata, using a range of concentrations $(125.0,250.0$, and $500.0 \mathrm{mg} / \mathrm{kg}$, p.o). Some inducers, such as aspirin and ethanol, were tested against gastric ulcers [209]. The standard positive control was misoprostol [250]. Several parameters, such as catalase, superoxide dismutase, mucin, and total protein, were measured and displayed a reduced index when treated with extracts. It has been suggested that the gastrointestinal effects of the extracts occur through an antioxidant pathway [250].

The antidiabetic activity of $T$. divaricata methanol extract was examined on alloxaninduced diabetic rats [251]. The results displayed substantial antidiabetic activity, with an additional reduction in the effect of oxidative damage observed in rats [251]. The extracts exhibited a similar mechanism in relation to the positive control, glibenclamide. The study of Kanthlal et al. [251] recommends that the methanol extract may alert the insulin receptors, therefore triggering a stimulation or production of beta-stem cells in the pancreas of the test subjects. The compound conophylline, which is often isolated from serval Tabernaemontana species, displayed antidiabetic activity [252]. Furthermore, conophylline was efficient in inducing the activity of activin A in AR42J cells, which in turn stimulated modification in endocrine cells [252]. The same compound was tested against diabetic rats [253]. In the study, increased plasma levels in normal and streptozotocin-induced diabetic rats were observed along with a significant decrease in blood glucose levels, indicative of antidiabetic activity [253]. In rat pancreatic acinar carcinoma cells and cultured rat pancreatic tissues, the compound conophylline was found to rapidly produce beta-cell differentiation, thus inducing differentiation into insulin-producing cells $[74,253]$.

Tabernaemontana catharinensis is often used for its antivenom properties [2]. Almeida et al. [202] examined the antivenom effects. The alkaloidal aqueous fractionation from the root bark of T. catharinensis was tested in vivo using Crotalus durissus terrificus [202]. It was observed that the extracts were able to extensively defuse the poisonous action of 
the venom [202]. Núñez et al. [254], investigated the antivenom activity of T. elegans. The study observed potential inhibition against Crotalus durissus cumanensis venom [254]. The antivenom potential of T. alternifolia root extract was tested in vitro and in vivo against Echis carinatus venom [255]. A range of pharmacological assays, including lethal toxicity determination, hemorrhagic, and neutralization studies, were carried out using chick embryo models [255]. The extracts showed promising results, since fibrinogen degradation, hemorrhage, and the venom-induced edema were significantly reduced in the models [255]. Recently, Vineetha and coauthors [116] investigated the in vitro and in vivo inhibitory effects of T. alternifolia methanolic root extract against Naja naja venom. Similarly, in their previous study, the fibrinogenolytic, direct, and indirect hemolytic activities for the neutralization of the venom were observed $[116,255]$. The results of the study yet again showed great potential, since fibrinogen and hemolytic were neutralized effectively, and the edema ratio was significantly reduced $[116,255]$. The latex of several Tabernaemontana species is habitually utilized for its wound-healing effects [3]. Subsequently, T. catharinensis is known for its many medicinal uses, including wound-healing effects [2].

\subsection{Silver Nanoparticles (AgNps)}

Recent trends in science have promoted the synthesis of AgNps in the field of nanotechnology [256]. Nanoparticles are extremely small materials that exhibit nanoscale dimensions ranging from 1-100 $\mathrm{nm}$ [257]. Due to their nanoscale size, these particles display a large surface area to volume ratio [258]. The properties of AgNps, such as their size, shape, and morphology, have enhanced their activity and thus are used in an extensive range of applications, such as health, medicine, food, textiles, and agricultural sectors [257]. Many metals have been evaluated for the synthesis of nanoparticles, such as gold (Au), copper $(\mathrm{Cu})$, and alloy of silver $\left(\mathrm{Ag}^{+}\right)$; however, comparable to these metals, reports have shown that $\mathrm{Ag}^{+}$is not considered a hazardous substance [259]. Gorchev and Ozolins [260] reported that minor amounts of $\mathrm{Ag}^{+}$were absorbed in laboratory test subjects ranging between $0 \%$ and $10 \%$. The two main methods used to obtain nanoparticles comprise of a "top-down" approach, which can be described as the process whereby nanoparticles are reduced in size until they reach a suitable material; conversely, the "bottom-down" approach involves the development of nanoparticles from an elemental entity, such as atoms and molecules [261]. The top-down method consists of chemical and physical techniques that are often energy consuming and produce imperfect nanoparticles [262]. Moreover, the bottom-down technique includes biological methods, which regularly produces colloidal dispersions of homogenous particles with fewer defects [263]. Current research has shown that the biological synthesis (i.e., the use of living organisms) of AgNps has driven investigations towards a "greener synthesis" approach, which is simple, cost-effective, environmentally friendly, and easily upscaled for large-scale synthesis [256,264]. According to Chouhan [258], the method of biological synthesis using a greener approach is relatively simple, as it requires less time and energy comparable to physical and chemical methods. This approach involves incubating crude aqueous extracts obtained from various plants or plant organs with an aqueous solution comprised of a metal salt, such as silver nitrate $\left(\mathrm{AgNO}_{3}\right)$ [261]. The reaction between the metabolites in the plant extract then reduces the metal ions in solution, thus metal nanoparticles are produced [261]. The use of environmentally friendly plant extracts was discovered to generate a considerable number of AgNps using $\mathrm{AgNO}_{3}$ as an inorganic metal [258]. Reported studies have found that $\mathrm{AgNps}$ exhibit significant antimicrobial activity and low toxicity to humans $[258,265,266]$.

Recently, several AgNps investigations have been conducted using Tabernaemontana species, with T. divaricata being the most investigated species (Table 10). In the study by Devaraj et al. [256], various T. divaricata extracts were used for biosynthesis, and characterized, and assessed for cytotoxicity against MCF-7 cell lines. The analysis showed that the average particle size ranged from $22.85 \mathrm{~nm}$ and the biosynthesized nanoparticles showed potential cytotoxicity to human breast cancer cells (MCF-7) [256]. It is highly probable that these nanoparticles could be regularly used in various sectors, such as medical, cosmetic, and 
food applications [256]. In another study conducted by Anbukkarasi et al. [267], T. divaricata extracts were used for biosynthesizing nanoparticles and the resulting biosynthesized nanoparticles were tested in vivo to prevent the formation of cataracts in selenite-induced cataractogenesis in Wistar rat pups [267]. It was revealed that rats induced with AgNps treatment displayed a reduction in lenticular alterations compared to plant extract-treated rats [267]. The results of the study recommend that biosynthesized AgNps using T. divaricata extracts may provide limitations of selenite-induced cataractogenesis in vivo, while simultaneous sustaining standard lenticular calcium homeostasis by avoiding adjustments in important lenticular proteins [267].

Table 10. Biological activity of synthesized silver nanoparticles using extracts isolated from Tabernaemontana species.

\begin{tabular}{cccc}
\hline Species & Plant Organ/Exudate & Extract & Biological Activity \\
\hline $\begin{array}{c}\text { Tabernaemontana } \\
\text { divaricata }\end{array}$ & Leaf & Aqueous and ethanol & $\begin{array}{c}\text { Cytotoxicity (human breast cancer } \\
\text { cell line-MCF-7), In vitro } \\
\text { antioxidant, anticataractogenic, } \\
\text { and in vivo anticataractogenic }\end{array}$ \\
\hline
\end{tabular}

\section{Conclusions}

The current review established an inclusive assessment of the major alkaloidal compounds within species belonging to the genus Tabernaemontana, which demonstrated pharmacological potential. The various secondary metabolites derived from Tabernaemontana species, such as terpenes, lactones, steroids, phenolics, flavonoids, and alkaloids, are often utilized in ethnobotany for their curative effects. Furthermore, these bioactive components have displayed numerous biological activities, including antimicrobial, antioxidant, anti-inflammatory, anticholinesterase, antineurodegenerative, anticancer, antidiabetic, antivenom, larvicidal, antihypertensive action, wound healing, and analgesic effects. However, despite the presence of biologically active chemical compounds within the genus Tabernaemontana, many species lack chemical and biological evaluation. Thus, further research is crucial to gain insight about the bioactive compounds and relative pharmacological activities of this esteemed genus.

Author Contributions: Conceptualization, methodology, C.M.N.; investigation and data curation, C.M.N. and Y.N.; validation, C.M.N.; Y.N., Y.H.D. and H.N.M., N.A.-S. and S.E.-H.; writing-original draft preparation, C.M.N. and Y.N.; writing-review and editing, Y.H.D., H.N.M., N.A.-S., and S.E.-H.; supervision, Y.N. and Y.H.D.; funding acquisition, Y.H.D.; S.E.-H. and N.A.-S. All authors have read and agreed to the published version of the manuscript.

Funding: Authors extend their appreciation to the Deanship of Scientific Research at King Saud University for funding this work through research group No. (RGP-1440-024).

Institutional Review Board Statement: Not applicable.

Informed Consent Statement: Not applicable.

Data Availability Statement: Not applicable.

Acknowledgments: Authors extend their appreciation to the Deanship of Scientific Research at King Saud University for funding this work through research group No. (RGP-1440-024) and the Researchers Support \& Services Unit (RSSU) for their technical support. Authors are thankful to the National Research Foundation of South Africa (118898) for supporting this work.

Conflicts of Interest: The authors declare no conflict of interest.

\section{References}

1. Van Beek, T.; Verpoorte, R.; Svendsen, A.; Leeuwenberg, A.; Bisset, N. Tabernaemontana L. (Apocynaceae): A review of its taxonomy, phytochemistry, ethnobotany and pharmacology. J. Ethnopharmacol. 1984, 10, 1-156. [CrossRef]

2. Silveira, D.; de Melo, A.F.; Magalhães, P.O.; Fonseca-Bazzo, Y.M. Tabernaemontana Species: Promising Sources of New Useful Drugs. In Studies in Natural Products Chemistry; Elsevier: Amsterdam, The Netherlands, 2017; Volume 54, pp. 227-289. [CrossRef] 
3. Marinho, F.F.; Simões, A.O.; Barcellos, T.; Moura, S. Brazilian Tabernaemontana genus: Indole alkaloids and phytochemical activities. Fitoterapia 2016, 114, 127-137. [CrossRef] [PubMed]

4. Simoes, A.O.; Endress, M.E.; Conti, E. Systematics and character evolution of Tabernaemontaneae (Apocynaceae, Rauvolfioideae) based on molecular and morphological evidence. TAXON 2010, 59, 772-790. [CrossRef]

5. Rapini, A. Taxonomy "under construction": Advances in the systematics of Apocynaceae, with emphasis on the Brazilian Asclepiadoideae. Rodriguésia 2012, 63, 075-088. [CrossRef]

6. Athipornchai, A. A Review on Tabernaemontana spp.: Multipotential Medicinal Plant. Asian J. Pharm. Clin. Res. 2018, 11, 45-53. [CrossRef]

7. Zhu, J.-P.; Guggisberg, A.; Kalt-Hadamowsky, M.; Hesse, M. Chemotaxonomic study of the genus Tabernaemontana (Apocynaceae) based on their indole alkaloid content. Plant Syst. Evol. 1990, 172, 13-34. [CrossRef]

8. Basavaraj, P.; Shivakumar, B.; Shivakumar, H. Anxiolytic activity of Tabernaemontana divaricata (Linn) R. Br. flowers extract in mice. J. Pharm. 2011, 2, 65-72. [CrossRef]

9. Nicola, C.; Salvador, M.; Gower, A.E.; Moura, S.; Echeverrigaray, S. Chemical Constituents Antioxidant and Anticholinesterasic Activity of Tabernaemontana catharinensis. Sci. World J. 2013, 2013, 519858. [CrossRef]

10. Boligon, A.A.; Athayde, M.L. Phytochemical investigation and cytotoxic properties of Tabernaemontana catharinensis A. DC. cultivated in Brazil. Res. J. Phytochem. 2012, 6, 127-131. [CrossRef]

11. Van Beek, T.; De Smidt, C.; Verpoorte, R. Phytochemical investigation of Tabernaemontana crassa. J. Ethnopharmacol. 1985, 14, 315-318. [CrossRef]

12. Fonge, B.A.; Tchetcha, D.J.; Nkembi, L. Diversity, Distribution, and Abundance of Plants in Lewoh-Lebang in the Lebialem Highlands of Southwestern Cameroon. Int. J. Biodivers. 2013, 2013, 642579. [CrossRef]

13. Abubakar, I.B.; Loh, H.-S. A review on ethnobotany, pharmacology and phytochemistry of Tabernaemontana corymbosa. J. Pharm. Pharmacol. 2016, 68, 423-432. [CrossRef] [PubMed]

14. Rahmatullah, M.; Kabir, A.A.B.T.; Rahman, M.M.; Hossan, M.S.; Khatun, Z.; Khatun, M.A.; Jahan, R. Ethnomedicinal practices among a minority group of Christians residing in Mirzapur village of Dinajpur District, Bangladesh. Adv. Nat. Sci. 2010, 4, 45-51.

15. Ong, H.C.; Chua, S.; Milow, P. Ethno-medicinal Plants Used by the Temuan Villagers in Kampung Jeram Kedah, Negeri Sembilan, Malaysia. Stud. Ethno-Med. 2011, 5, 95-100. [CrossRef]

16. Beentje, H.; Adamson, J.; Bhanderi, D. Kenya Trees, Shrubs, and Lianas; National Museums of Kenya: Nairobi, Kenya, 1994.

17. Munayi, R.R. Phytochemical Investigation of Bridelia micrantha and Tabernaemontana ventricosa for Cytotoxic Principles against Drug Sensitive Leukemia Cell Lines. Ph.D. Thesis, University of Nairobi, Nairobi, Kenya, 2016.

18. Schmidt, E.; Lotter, M.; McCleland, W. Trees and Shrubs of Mpumalanga and Kruger National Park; Jacana Media: Johannesburg, South Africa, 2002; pp. 566-569.

19. Schmelzer, G.B.; Gurib-Fakim, A. Plant Resources of Tropical Africa (PROTA). In Medicinal Plants, 1st ed.; Backhuys Publishers: Wageningen, The Netherlands, 2008; Volume 1, pp. 597-598.

20. Pallant, C.; Cromarty, A.D.; Steenkamp, V. Effect of an alkaloidal fraction of Tabernaemontana elegans (Stapf.) on selected micro-organisms. J. Ethnopharmacol. 2012, 140, 398-404. [CrossRef] [PubMed]

21. Arnold, H.-J.; Gulumian, M. Pharmacopoeia of traditional medicine in Venda. J. Ethnopharmacol. 1984, 12, 35-74. [CrossRef]

22. Steenkamp, V.; Fernandes, A.; Van Rensburg, C. Screening of Venda medicinal plants for antifungal activity against Candida albicans. S. Afr. J. Bot. 2007, 73, 256-258. [CrossRef]

23. De Assis, C.M.; Moreno, P.R.H.; Young, M.C.M.; Campos, I.P.D.A.; Suffredini, I.B. Isolamento e avaliação da atividade biológica dos alcalóides majoritários de Tabernaemontana angulata Mart. ex Müll. Arg., Apocynaceae. Rev. Bras. Farm. 2009, 19 , 626-631. [CrossRef]

24. Araujo, A.R.; Kascheres, C.; Fujiwara, F.; Marsaioli, A.J. Catharinensine, an oxindole alkaloid from Peschiera catharinensis. Phytochemistry 1984, 23, 2359-2363. [CrossRef]

25. Cardoso, C.A.L.; Vilegas, W. Droplet counter-current chromatography of indole alkaloids from Tabernaemontana hilariana. Phytochem. Anal. 1999, 10, 60-63. [CrossRef]

26. Santos, A.K.L.; Machado, L.L.; Bizerra, A.M.C.; Monte, F.J.Q.; Santiago, G.M.P.; Braz-Filho, R.; Lemos, T.L.G. New Indole Alkaloid from Peschiera affinis (Apocynaceae). Nat. Prod. Commun. 2012, 7, 729-730. [CrossRef]

27. Braga, R.M.; Filho, H.F.L.; Reis, F.A.M. ${ }^{13}$ C NMR analysis of alkaloids from Peschiera fuchsiaefolia. Phytochemistry 1984, $23,175-178$. [CrossRef]

28. Spitzer, V.; Rates, S.M.K.; Henriques, A.T.; Marx, F. The Fatty Acid Composition of the Seed Oil of Peschiera australis (Apocynaceae). Fette Seifen Anstrichm. 1995, 97, 334-335. [CrossRef]

29. Lemos, T.L.G.; Andrade, C.H.S.; Guimarães, A.M.; Wolter-Filho, W.; Braz-Filho, R. 19-Epivoacristine, an Iboga Alkaloid Isolated from Peschiera affinis. J. Braz. Chem. Soc. 1996, 7, 123-126. [CrossRef]

30. Cardoso, C.A.; Vilegas, W.; Pozetti, G.L. Gas chromatographic analysis of indole alkaloids from Tabernaemontana hilariana. J. Chromatogr. A 1997, 788, 204-206. [CrossRef]

31. Cardoso, C.A.; Vilegas, W.; Honda, N.K. Qualitative determination of indole alkaloids, triterpenoids and steroids of Tabernaemontana hilariana. J. Chromatogr. A 1998, 808, 264-268. [CrossRef] 
32. Batina, M.D.F.C.; Cintra, A.C.O.; Veronese, E.L.G.; Lavrador, M.A.S.; Giglio, J.R.; Pereira, P.S.; Dias, D.A.; França, S.C.; Sampaio, S.V. Inhibition of the Lethal and Myotoxic Activities of Crotalus durissus terrificus Venom by Tabernaemontana catharinensis: Identification of One of the Active Components. Planta Med. 2000, 66, 424-428. [CrossRef]

33. Pereira, P.S.; França, S.C.; De Oliveira, P.V.A.; Breves, C.M.D.S.; Pereira, S.I.V.; Sampaio, S.V.; Nomizo, A.; Dias, D.A. Chemical constituents from Tabernaemontana catharinensis root bark: A brief NMR review of indole alkaloids and in vitro cytotoxicity. Química Nova 2008, 31, 20-24. [CrossRef]

34. Gonçalves, D.; Araújo, J.; Francisco, M.; Coelho, M.; Franco, J. Avaliação da atividade antimicrobiana in vitro do extrato de Tabernaemontana catharinensis A. DC. Rev. Bras. Plantas Med. 2011, 13, 197-202. [CrossRef]

35. Cava, M.P.; Nomura, K.; Talapatra, S.K.; Mitchell, M.J.; Schlessinger, R.H.; Buck, K.T.; Beal, J.L.; Douglas, B.; Raffauf, R.F.; Weisbach, J.A. Alkaloids of Stephania glabra. Direct chemical correlation of the absolute configuration of some benzyltetrahydroisoquinoline, proaporphine, and aporphine alkaloids. New protoberberine alkaloid. J. Org. Chem. 1968, 33, 2785-2789. [CrossRef]

36. Kam, T.-S.; Anuradha, S. Alkaloids from Tabernaemontana divaricata. Phytochemistry 1995, 40, 313-316. [CrossRef]

37. Kam, T.-S.; Sim, K.-M.; Lim, T.-M. Tronoharine, a novel hexacyclic indole alkaloid from a Malayan Tabernaemontana. Tetrahedron Lett. 1999, 40, 5409-5412. [CrossRef]

38. Kam, T.-S.; Sim, K.-M.; Lim, T.-M. Voastrictine, a novel pentacyclic quinolinic alkaloid from Tabernaemontana. Tetrahedron Lett. 2000, 42, 4721-4723. [CrossRef]

39. Kam, T.-S.; Sim, K.-M. Five New Iboga Alkaloids from Tabernaemontana corymbosa. J. Nat. Prod. 2002, 65, 669-672. [CrossRef]

40. Kam, T.-S.; Sim, K.-M.; Pang, H.-S. New Bisindole Alkaloids from Tabernaemontana corymbosa. J. Nat. Prod. 2003, 66, 11-16. [CrossRef] [PubMed]

41. Kam, T.-S.; Sim, K.-M. Conodirinines A and B, Novel Vobasine-Iboga Bisindoles Incorporating an Additional Tetrahydro-1,3oxazine Unit on the Vobasinyl Moiety. Helv. Chim. Acta 2003, 86, 122-126. [CrossRef]

42. Cava, M.; Talapatra, S.; Weisbach, J.; Douglas, B.; Raffauf, R.; Beal, J. Gabunine: A natural dimeric indole derived from perivine. Tetrahedron Lett. 1965, 6, 931-935. [CrossRef]

43. Rastogi, K.; Kapil, R.S.; Popli, S.P. New alkaloids from Tabernaemontana divaricata. Phytochemistry 1980, 19, 1209-1212. [CrossRef]

44. Kingston, D.G.I.; Li, B.T.; Ionescu, F. Plant Anticancer Agents III: Isolation of Indole and Bisindole Alkaloids from Tabernaemontana holstii Roots. J. Pharm. Sci. 1977, 66, 1135-1138. [CrossRef] [PubMed]

45. Mairura, F. Medicinal plants: Tabernaemontana crass Benth. Prota 2006, 1, 589-591.

46. Perera, P.; van Beek, T.A.; Verpoorte, R. Dichomine, a Novel Type of Iboga Alkaloid. Planta Med. 1983, 49, 232-235. [CrossRef]

47. Perera, P.; Sandberg, F.; Van Beek, T.; Verpoorte, R. Alkaloids of stem and rootbark of Tabernaemontana dichotoma. Phytochemistry 1985, 24, 2097-2104. [CrossRef]

48. Arambewela, L.S.; Ranatunge, T. Indole alkaloids from Tabernaemontana divaricata. Phytochemistry 1991, 30, 1740-1741. [CrossRef]

49. Kam, T.-S.; Pang, H.-S.; Choo, Y.-M.; Komiyama, K. Biologically Active Ibogan and Vallesamine Derivatives from Tabernaemontana divaricata. Chem. Biodivers. 2004, 1, 646-656. [CrossRef] [PubMed]

50. Kam, T.-S.; Loh, K.-Y.; Lim, L.-H.; Loong, W.-L.; Chuah, C.-H.; Wei, C. New alkaloids from the leaves of Tabernaemontana divaricata. Tetrahedron Lett. 1992, 33, 969-972. [CrossRef]

51. Kam, T.-S.; Pang, H.-S.; Lim, T.-M. Biologically active indole and bisindole alkaloids from Tabernaemontana divaricata. Org. Biomol. Chem. 2003, 1, 1292-1297. [CrossRef]

52. Henriques, A.; Melo, A.; Moreno, P.R.H.; Ene, L.; Henriques, J.; Schapoval, E.E.S. Ervatamia coronaria: Chemical constituents and some pharmacological activities. J. Ethnopharmacol. 1996, 50, 19-25. [CrossRef]

53. Ingkaninan, K.; Changwijit, K.; Suwanborirux, K. Vobasinyl-iboga bisindole alkaloids, potent acetylcholinesterase inhibitors from Tabernaemontana divaricate root. J. Pharm. Pharmacol. 2006, 58, 847-852. [CrossRef] [PubMed]

54. Singh, B.; Sharma, R.A.; Vyas, G.K. Antimicrobial, Antineoplastic and Cytotoxic Activities of Indole Alkaloids from Tabernaemontana divaricata (L.) R.Br. Curr. Pharm. Anal. 2011, 7, 125-132. [CrossRef]

55. Van der Heijden, R.; Brouwer, R.L.; Verpoorte, R.; Wijnsma, R.; van Beek, T.A.; Harkes, A.A.; Svendsen, A.B. Indole Alkaloids from a Callus Culture of Tabernaemontana elegans. Phytochemistry 1986, 25, 843-846. [CrossRef]

56. Danieli, B.; Palmisano, G.; Gabetta, B.; Martinelli, E.M. Tabernaelegantinines C and D, two new bisindole alkaloids containing a cyano group from Tabernaemontana elegans Stapf. Part 2. J. Chem. Soc. 1980, 1, 601-606.

57. Wolter Filho, W.; Pinheiro, M.L.B.; Rocha, A.I. Alcalóides de Tabernaemontana heterophylla Vahl (Apocynaceae). Acta Amazon. 1983, 13, 409-412. [CrossRef]

58. Monnerat, C.S.; De Souza, J.J.; Mathias, L.; Braz-Filho, R.; Vieira, I.J.C. A new indole alkaloid isolated from Tabernaemontana hystrix steud (Apocynaceae). J. Braz. Chem. Soc. 2005, 16, 1331-1335. [CrossRef]

59. Hwang, B.; Weisbach, J.A.; Douglas, B.; Raffauf, R.F.; Cava, M.P.; Bessho, K. Problems in chemotaxonomy. V. Alkaloids of Peschiera lundii. Isolation and structure elucidation of voacristine pseudoindoxyl and iboxygaine hydroxyindolenine. J. Org. Chem. 1969, 34, 412-415. [CrossRef]

60. De Souza, J.J.; Mathias, L.; Vieira, I.J.C.; Braz-Filho, R. Two New Indole Alkaloids from Tabernaemontana hystrix Steud. (Apocynaceae). Helv. Chim. Acta 2010, 93, 422-429. [CrossRef]

61. Vieira, I.J.; Medeiros, W.L.; Monnerat, C.S.; Souza, J.J.; Mathias, L.; Braz-Filho, R.; Pinto, A.C.; Sousa, P.M.; Rezende, C.M.; Epifanio, R.D.A. Two fast screening methods (GC-MS and TLC-ChEI assay) for rapid evaluation of potential anticholinesterasic indole alkaloids in complex mixtures. An. Acad. Bras. Ciências 2008, 80, 419-426. [CrossRef] 
62. Jahodář, L.; Votický, Z.; Cava, M.P. Geissoschizol in Peschiera laeta. Phytochemistry 1974, 13, 2880-2881. [CrossRef]

63. Voticky, Z.; Jahodar, L.; Cava, M.P. Alkaloids from Peschiera laeta MART. Collect. Czechoslov. Chem. Commun. 1977, $42,1403-1406$. [CrossRef]

64. You, M.; Ma, X.; Mukherjee, R.; Farnsworth, N.R.; Cordell, G.A.; Kinghorn, A.D.; Pezzuto, J.M. Indole Alkaloids from Peschiera laeta That Enhance Vinblastine-Mediated Cytotoxicity with Multi-drug-Resistant Cells. J. Nat. Prod. 1994, 57, 1517-1522. [CrossRef]

65. Medeiros, W.L.B.; Vieira, I.J.C.; Mathias, L.; Braz-Filho, R.; Schripsema, J. A new natural auaternary indole slkaloid isolated from Tabernaemontana laeta Mart. (Apocynaceae). J. Braz. Chem. Soc. 2001, 12, 368-372. [CrossRef]

66. Niemann, C.; Kessel, J.W. The Isolation of Rupicoline and Montanine, Two Pseudoindoxyl Alkaloids of Tabernaemontana Rupicola Benth. J. Org. Chem. 1966, 31, 2265-2269. [CrossRef]

67. Figueiredo, E.R.; Vieira, I.J.C.; De Souza, J.J.; Braz-Filho, R.; Mathias, L.; Kanashiro, M.M.; Côrtes, F.H. Isolamento, identificação e avaliação da atividade antileucêmica de alcaloides indólicos monoterpênicos de Tabernaemontana salzmannii (A. DC.), Apocynaceae. Rev. Bras. Farm. 2010, 20, 675-681. [CrossRef]

68. Damak, M.; Ahond, A.; Potier, P. Bonafousine and isobonafousine, dimeric alkaloids from Bonafousia tetrastachya (Humboldt, Bonpland et Kunth) Markgraf (apocynaceae). Bull. Soc. Chim. Fr. 1980, 9, 490-495. [CrossRef]

69. Gower, A.E.; Pereira, B.D.S.; Marsaioli, A.J. Indole alkaloids from Peschiera campestris. Phytochemistry 1986, 25, 2908-2910. [CrossRef]

70. Pratchayasakul, W.; Pongchaidecha, A.; Chattipakorn, N.; Chattipakorn, S. Ethnobotany and ethnopharmacology of Tabernaemontana divaricata. Indian J. Med. Res. 2008, 127, 317-335.

71. Basumatary, A.R. Preliminary phytochemical screening of some compounds from plant stem bark extracts of Tabernaemontana divaricata Linn. used by Bodo Community at Kokrajhar District, Assam, India. Arch. Appl. Sci. Res. 2016, 8, 47-52.

72. Garga, D.; Das, T. Preliminary phytochemical screening and anti-inflammatory effect of the Aqueous extract of Tabernaemontana divaricata flower in wister rats. J. Curr. 2017, 9, 9-12. [CrossRef]

73. Kuete, V.; Manfouo, R.N.; Beng, V.P. Toxicological evaluation of the hydroethanol extract of Tabernaemontana crassa (Apocynaceae) stem bark. J. Ethnopharmacol. 2010, 130, 470-476. [CrossRef]

74. Zhang, H.-R.; Li, D.; Cao, H.; Lu, X.; Chu, Y.-K.; Bai, Y.-F.; Jin, Y.-P.; Peng, S.; Dou, Z.; Hua, J.-L. Conophylline Promotes the Proliferation of Immortalized Mesenchymal Stem Cells Derived from Fetal Porcine Pancreas (iPMSCs). J. Integr. Agric. 2013, 12, 678-686. [CrossRef]

75. Mehrbod, P.; Abdalla, M.A.; Njoya, E.M.; Ahmed, A.S.; Fotouhi, F.; Farahmand, B.; Gado, D.A.; Tabatabaian, M.; Fasanmi, O.G.; Eloff, J.N.; et al. South African medicinal plant extracts active against influenza A virus. BMC Complement. Altern. Med. 2018, 18, 1-10. [CrossRef]

76. Fierascu, R.C.; Ortan, A.; Fierascu, I.C.; Fierăscu, I. In vitro and in vivo evaluation of antioxidant properties of wild-growing plants. A short review. Curr. Opin. Food Sci. 2018, 24, 1-8. [CrossRef]

77. Toghueo, R.M.K.; Boyom, F.F. Endophytes from ethno-pharmacological plants: Sources of novel antioxidants-A systematic review. Biocatal. Agric. Biotechnol. 2019, 22, 101430. [CrossRef]

78. Shori, A.B. Screening of antidiabetic and antioxidant activities of medicinal plants. J. Integr. Med. 2015, 13, 297-305. [CrossRef]

79. Magalhães, L.M.; Segundo, M.A.; Reis, S.; Lima, J.L. Methodological aspects about in vitro evaluation of antioxidant properties. Anal. Chim. Acta 2008, 613, 1-19. [CrossRef] [PubMed]

80. Boligon, A.A.; De Freitas, R.B.; De Brum, T.F.; Piana, M.; Belke, B.V.; Rocha, J.B.T.; Athayde, M.L. Phytochemical constituents and in vitro antioxidant capacity of Tabernaemontana catharinensis A. DC. Free Radic. Antioxid. 2013, 3, 77-80. [CrossRef]

81. Shrikanth, V.M.; Janardhan, B.; Dhananjaya, B.L.; Muddapura, U.M.; More, S.S. Antimicrobial and antioxidant activity of methanolic root extract of Tabernaemontana alternifolia L. Int. J. Pharm. Pharm. Sci. 2015, 7, 66-69.

82. Jain, S.; Jain, A.; Jain, N.; Jain, D.; Balekar, N. Phytochemical investigation and evaluation of in vitro free radical scavenging activity of Tabernaemontana divaricata Linn. Nat. Prod. Res. 2010, 24, 300-304. [CrossRef]

83. Wasupongpun, W.; Premkaisorn, P. Evaluation of Antioxidant Activity of Eleven Thai Medicinal Herbs. Sci. J. 2010, $26,29-38$.

84. Baskar, A.A.; Numair, K.-S.A.; AlSaif, M.-A.; Ignacimuthu, S. In vitro antioxidant and antiproliferative potential of medicinal plants used in traditional Indian medicine to treat cancer. Redox Rep. 2012, 17, 145-156. [CrossRef]

85. Sathishkumar, T.; Baskar, R. Evaluation of antioxidant properties of Tabernaemontana heyneana Wall. leaves. Indian J. Nat. Prod. Resour. 2012, 3, 197-207.

86. Manasa, D.J.; Chandrashekar, K.R. Antioxidant and antimicrobial activities of Tabernaemontana heyneana Wall. An endemic plant of Western Ghats. Int. J. Pharm. Sci. 2015, 7, 311-315.

87. Santos, A.K.; Magalhaes, T.S.; Monte, F.J.; Mattos, M.C.; Oliveira, M.C.; Almeida, M.M.; Lemos, T.L.; Braz-Filho, R. Iboga alkaloids from Peschier aaffinis (Apocynaceae)-unequivocal $1 \mathrm{H}$ and $13 \mathrm{C}$ chemical shift assignments: Antioxidant activity. Quim. Nova 2009, 32, 1834-1838. [CrossRef]

88. Pereira, C.G.; Leal, P.F.; Sato, D.N.; Meireles, M.A. SFE of pharmacological compounds from Tabernaemontana catharinensis: Analysis of the antioxidant and antimycobacterial activities. In Proceedings of the 6th International Symposium on Supercritical Fluids, Versailles, France, 28-30 April 2003.

89. Boligon, A.A.; Piana, M.; Schawnz, T.G.; Pereira, R.P.; Rocha, J.B.T.; Athayde, M.L. Chromatographic Analysis and Antioxidant Capacity of Tabernaemontana catharinensis. Nat. Prod. Commun. 2014, 9, 61-64. [CrossRef] [PubMed] 
90. Piana, M.; Boligon, A.A.; De Brum, T.F.; Zadra, M.; Belke, B.V.; Froeder, A.L.; Frohlich, J.K.; Nunes, L.T.; Pappis, L.; Boligon, A.A.; et al. Phytochemical analysis and antioxidant capacity of Tabernaemontana catharinensis A. DC. Fruits and branches. Ann. Acad. Bras. Ciências 2014, 86, 881-888. [CrossRef] [PubMed]

91. Pergher, D.; Picolotto, A.; Rosales, P.F.; Machado, K.G.; Cerbaro, A.F.; França, R.T.; Salvador, M.; Roesch-Ely, M.; Tasso, L.; Figueiredo, J.G.; et al. Antinociceptive and antioxidant effects of extract enriched with active indole alkaloids from leaves of Tabernaemontana catharinensis A. DC. J. Ethnopharmacol. 2019, 239, 111863. [CrossRef]

92. Sari, R.; Conterno, P.; Da Silva, L.D.; De Lima, V.A.; Oldoni, T.L.C.; Thomé, G.R.; Carpes, S. Extraction of Phenolic Compounds from Tabernaemontana catharinensis Leaves and Their Effect on Oxidative Stress Markers in Diabetic Rats. Molecules 2020, $25,2391$. [CrossRef] [PubMed]

93. Jolly, C.; Thambi, P.; Kuzhivelil, B.; Sabu, M. Antioxidant and anti inflammatory activities of the flowers of Tabernaemontana coronaria (L) R.Br. Indian J. Pharm. Sci. 2006, 68, 352. [CrossRef]

94. Gupta, M.; Kanti, M.U.; Gomathi, P.; Sambath, K.R. Antioxidant and free radical scavenging activities of Ervatamia coronaria Stapf. leaves. Iran. J. Pharm. Res. 2010, 3, 119-126.

95. Zulkefli, H.N.; Mohamad, J.; Abidin, N.Z. Antioxidant activity of methanol extract of Tinospora crispa and Tabernaemontana corymbosa. Sains Malays. 2013, 42, 697-706.

96. Rumzhum, N.N.; Rahman, M.; Kazal, K. Antioxidant and cytotoxic potential of methanol extract of Tabernaemontana divaricata leaves. Int. Curr. Pharm. J. 2012, 1, 27-31. [CrossRef]

97. Venkatachalapathi, S.; Saranya, C.; Ravi, S. Isolation and Characterization of Bio Active Compounds from Tabernaemontana divaricata and a Study of its Antioxidant and Antibacterial Activity. Indo Am. J. Pharm. Res. 2014, 4, 2401-2406.

98. Khan, M.S.A. Gastroprotective Effect of Tabernaemontana divaricata (Linn.) R.Br. Flower Methanolic Extract in Wistar Rats. Br. J. Pharm. Res. 2011, 1, 88-98. [CrossRef]

99. Choudhary, R.; Saroha, A.E.; Swarnkar, P. Screening of endogenous antioxidants in some medicinal plants. Toxicol. Environ. Chem. 2011, 93, 656-664. [CrossRef]

100. Mueller, M.O.; Janngeon, K.; Puttipan, R.I.; Unger, F.M.; Viernstein, H.; Okonogi, S.I. Anti-inflammatory, antibacterial and antioxidant activities of Thai medicinal plants. Int. J. Pharm. Pharm. Sci. 2015, 7, 123-128.

101. Anbukkarasi, M.; Thomas, P.A.; Sheu, J.-R.; Geraldine, P. In vitro antioxidant and anticataractogenic potential of silver nanoparticles biosynthesized using an ethanolic extract of Tabernaemontana divaricata leaves. Biomed. Pharmacother. 2017, 91, 467-475. [CrossRef]

102. Anbukkarasi, M.; Sundararajan, M.; Venkadeswaran, K.; Ruban, V.V.; Anand, T.; Geraldine, P. Antihypercholesterolemic, antioxidative and anti-inflammatory potential of an extract of the plant Tabernaemontana divaricata in experimental rats fed an atherogenic diet. Biocatal. Agric. Biotechnol. 2019, 19, 101115. [CrossRef]

103. Kalaimagal, C. In vitro antioxidant activity in ethanolic leaf extract of Tabernaemontana divaricata (L.). Int. J. Bio-Pharma Res. 2019, 8, 2602-2606.

104. Santhi, R.; Annapurani, S. Preliminary evaluation of In vitro and In vivo antioxidative and antitumor activities of flavonoid extract of Tabernaemontana divaricata leaves in Ehrlich's lymphoma and Dalton's lymphoma ascites model. J. Cancer Res. Ther. 2020, 16, 78-87. [CrossRef]

105. Khongsombat, O.; Nakdook, W.; Ingkaninan, K. Inhibitory effects of Tabernaemontana divaricata root extract on oxidative stress and neuronal loss induced by amyloid $\beta 25-35$ peptide in mice. J. Tradit. Complement. Med. 2018, 8, 184-189. [CrossRef]

106. Mandlik Satish, K.; Saugat, A.; Deshpande Ameya, A. Application of Simplex Lattice Design in Formulation and Development of Buoyant Matrices of Dipyridamole. J. Appl. Pharm. Sci. 2012, 2, 107-111. [CrossRef]

107. Bhavana, N.S.; Prakash, H.S.; Nalini, M.S. Fungal Endophytes from Tabernaemontana heyneana Wall. (Apocynaceae), their Molecular Characterization, L-asparaginase and Antioxidant Activities. Jordan J. Biol. Sci. 2020, 13, 543-550.

108. Banik, S. Evaluation of thrombolytic, membrane stabilizing, and antioxidant activities of methanolic extract of Tabernaemontana recurva Roxb. Discov. Phytomed. 2017, 4, 17. [CrossRef]

109. Elgorashi, E.; McGaw, L.J. African plants with in vitro anti-inflammatory activities: A review. S. Afr. J. Bot. 2019, 126, 142-169. [CrossRef]

110. Calixto, J.B.; Otuki, M.F.; Santos, A.R.S. Anti-Inflammatory Compounds of Plant Origin. Part I. Action on Arachidonic Acid Pathway, Nitric Oxide and Nuclear Factor к B (NF-kB). Planta Med. 2003, 69, 973-983. [CrossRef] [PubMed]

111. Iwalewa, E.O.; McGaw, L.J.; Naidoo, V.; Eloff, J.N. Inflammation: The foundation of diseases and disorders. A review of phytomedicines of South African origin used to treat pain and inflammatory conditions. Afr. J. Biotechnol. 2007, 6, $2868-2885$. [CrossRef]

112. Rashid, R.; Sharma, M.; Wani, M.H. Anti-inflammatory activity of medicinal plants native to Jammu and Kashmir: A review. J. Pharm. Innov. 2018, 7, 279-281.

113. Heras, B.D.L.; Slowing, K.; Benedí, J.; Carretero, E.; Ortega, T.; Toledo, C.; Bermejo, P.; Iglesias, I.; Abad, M.; Gómez-Serranillos, M.P.; et al. Antiinflammatory and antioxidant activity of plants used in traditional medicine in Ecuador. J. Ethnopharmacol. 1998, 61, 161-166. [CrossRef]

114. Calixto, J.B.; Cabrini, D.A.; Ferreira, J.; Campos, M.M. Kinins in pain and inflammation. Pain 2000, 87, 1-5. [CrossRef]

115. Jain, S.; Sharma, P.; Ghule, S.; Jain, A.; Jain, N. In vivo anti-inflammatory activity of Tabernaemontana divaricata leaf extract on male albino mice. Chin. J. Nat. Med. 2013, 11, 472-476. [CrossRef] 
116. Vineetha, M.; Bhavya, J.; Veena, S.; Mirajkar, K.K.; Muddapur, U.; Ananthraju, K.; Zameer, F.; More, S.S. In vitro and in vivo inhibitory effects of Tabernaemontana alternifolia against Naja naja venom. Saudi Pharm. J. 2020, 28, 692-697. [CrossRef]

117. Zhang, D.-B.; Yu, D.-G.; Sun, M.; Zhu, X.-X.; Yao, X.-J.; Zhou, S.-Y.; Chen, J.-J.; Gao, K. Ervatamines A-I, Anti-inflammatory Monoterpenoid Indole Alkaloids with Diverse Skeletons from Ervatamia hainanensis. J. Nat. Prod. 2015, 78, 1253-1261. [CrossRef]

118. Rates, S.M.K.; Schapoval, E.E.S.; Souza, L.; Henriques, A.T. Chemical constituents and pharmacological activities of Peschieraaustralis. Int. J. Pharmacogn. 1993, 31, 288-294. [CrossRef]

119. Gomes, R.; Neto, A.; Melo, V.; Fernandes, V.; Dagrava, G.; Santos, W.; Pereira, P.S.; Couto, L.; Beleboni, R.O. Antinociceptive and anti-inflammatory activities of Tabernaemontana catharinensis. Pharm. Biol. 2009, 47, 372-376. [CrossRef]

120. Camponogara, C.; Casoti, R.; Brusco, I.; Piana, M.; Boligon, A.A.; Cabrini, D.A.; Trevisan, G.; Ferreira, J.; Silva, C.R.; Oliveira, S.M. Tabernaemontana catharinensis leaves exhibit topical anti-inflammatory activity without causing toxicity. J. Ethnopharmacol. 2019, 231, 205-216. [CrossRef] [PubMed]

121. Brum, E.D.S.; Becker, G.; Fialho, M.F.P.; Casoti, R.; Trevisan, G.; Oliveira, S.M. TRPA1 involvement in analgesia induced by Tabernaemontana catharinensis ethyl acetate fraction in mice. Phytomedicine 2019, 54, 248-258. [CrossRef] [PubMed]

122. Camponogara, C.; Casoti, R.; Brusco, I.; Piana, M.; Boligon, A.A.; Cabrini, D.A.; Trevisan, G.; Ferreira, J.; Silva, C.R.; Oliveira, S.M. Tabernaemontana catharinensis leaves effectively reduce the irritant contact dermatitis by glucocorticoid receptor-dependent pathway in mice. Biomed. Pharmacother. 2019, 109, 646-657. [CrossRef]

123. Marques, J.I.; Alves, J.S.F.; Torres-Rêgo, M.; Furtado, A.A.; Siqueira, E.M.D.S.; Galinari, É.; Araújo, D.F.S.; Guerra, G.C.B.; De Azevedo, E.P.; Fernandes-Pedrosa, M.D.F.; et al. Phytochemical Analysis by HPLC-HRESI-MS and Anti-Inflammatory Activity of Tabernaemontana catharinensis. Int. J. Mol. Sci. 2018, 19, 636. [CrossRef]

124. Kanthlal, S.K.; Suresh, V.; Arunachalam, G.; Frank, P.R.; Kameshwaran, S. In vivo evaluation of analgesic and antipyretic activity of aerial parts of Tabernaemontana divaricata in experimental animal models. Pharmacologyonline 2011, 3, 1127-1133.

125. Ingkaninan, K.; Ijzerman, A.P.; Taesotikul, T.; Verpoorte, R. Isolation of Opioid-active Compounds from Tabernaemontana pachysiphon leaves. J. Pharm. Pharmacol. 1999, 51, 1441-1446. [CrossRef] [PubMed]

126. Taesotikul, T.; Panthong, A.; Kanjanapothi, D.; Verpoorte, R.; Scheffer, J.J.C. Anti-inflammatory, antipyretic and antinociceptive activities of Tabernaemontana pandacaqui Poir. J. Ethnopharmacol. 2003, 84, 31-35. [CrossRef]

127. Okuyama, E.; Gao, L.-H.; Yamazaki, M. Analgesic Components from Bornean Medicinal Plants, Tabernaemontana pauciflora Blume and Tabernaemontana pandacaqui POIR. Chem. Pharm. Bull. 1992, 40, 2075-2079. [CrossRef]

128. Bhadane, B.S.; Patil, M.P.; Maheshwari, V.L.; Patil, R.H. Ethnopharmacology, phytochemistry, and biotechnological advances of family Apocynaceae: A review. Phytother. Res. 2018, 32, 1181-1210. [CrossRef]

129. Ncube, N.S.; Afolayan, A.J.; Okoh, A.I. Assessment techniques of antimicrobial properties of natural compounds of plant origin: Current methods and future trends. Afr. J. Biotechnol. 2008, 7, 1797-1806. [CrossRef]

130. Jain, S.K.; Sharma, P.; Balekar, N.; Jain, D.K. Antioxidant and antifungal activity of some medicinal plant extracts. J. Drug Deliv. Ther. 2017, 7, 189-191.

131. Suffredini, I.B.; Bacchi, E.M.; Sakuda, T.M.K.; Ohara, M.T.; Younes, R.N.; Varella, A.D. Antibacterial activity of Apocynaceae extracts and MIC of Tabernaemontana angulata stem organic extract. Rev. Bras. Ciências Farm. 2002, 38, 89-94. [CrossRef]

132. Boligon, A.A.; Piana, M.; Kubiça, T.F.; Mario, D.N.; Dalmolin, T.V.; Bonez, P.C.; Weiblen, R.; Lovato, L.T.; Alves, S.H.; Campos, M.M.; et al. HPLC analysis and antimicrobial, antimycobacterial and antiviral activities of Tabernaemontana catharinensis A. DC. J. Appl. Biomed. 2015, 13, 7-18. [CrossRef]

133. Medeiros, M.R.F.; Prado, L.A.D.M.; Fernandes, V.C.; Figueiredo, S.S.; Coppede, J.; Martins, J.; Fiori, G.M.L.; Martinez-Rossi, N.M.; Beleboni, R.O.; Contini, S.H.T.; et al. Antimicrobial Activities of Indole Alkaloids from Tabernaemontana catharinensis. Nat. Prod. Commun. 2011, 6, 193-196. [CrossRef] [PubMed]

134. Zacchino, S.; Santecchia, C.; Lopez, S.; Gattuso, S.; Muñoz, J.D.D.; Cruañes, A.; Vivot, E.; Cruañes, M.D.C.; Salinas, A.; De Ruiz, R.; et al. In vitro antifungal evaluation and studies on mode of action of eight selected species from the Argentine flora. Phytomedicine 1998, 5, 389-395. [CrossRef]

135. Perera, P.; Kanjanapoothi, D.; Sandberg, F.; Verpoorte, R. Screening for biological activity of different plant parts of Tabernaemontana dichotoma, known as divi kaduru in Sri Lanka. J. Ethnopharmacol. 1984, 11, 233-241. [CrossRef]

136. Kumari, S.; Mazumder, A.; Bhattacharya, S. Pharmacognostical and antimicrobial studies of the stem of Tabernaemontana divaricata Linn. Int. J. Pharm. Sci. 2015, 7, 101-104.

137. Wankhede, S.B.; Routh, M.M.; Rajput, S.B.; Karuppayil, S.M. Antifungal properties of selected plants of Apocynaceae family against the human fungal pathogen Candida albicans. Int. Curr. Pharm. J. 2013, 2, 122-125. [CrossRef]

138. Rakkimuthu, R.; Nithiyakamatchi, R.; Sathishkumar, P.; Ananda Kumar, A.M.; Sowmiya, D. In vitro antifungal activity of formulated floral extracts against Malassezia furfur. Int. J. Anal. Exp. Modal Anal. 2019, 6, 1-10.

139. Satapathy, R.; Beura, S. Management of Colletotrichum gloeosporioides (Penz.) Causing Cashew Anthracnose through Botanicals. Int. J. Curr. Microbiol. Appl. Sci. 2018, 7, 3539-3543. [CrossRef]

140. Pallant, C.; Steenkamp, V. In-vitro bioactivity of Venda medicinal plants used in the treatment of respiratory conditions. Hum. Exp. Toxicol. 2009, 27, 859-866. [CrossRef] [PubMed]

141. Uwumarongie, O.H.; Onwukaeme, D.N.; Obasuyi, O. Antimicrobial activity of the methanolic leaf extract of Tabernaemontana pachysiphon stapf. (Apocynaceae). Niger. J. Nat. Prod. Med. 2007, 11, 23-25. [CrossRef] 
142. Uwumarongie, H.O.; Onwukaeme, D.N.; Bafor, E.E. Antiulcer effects and elements of Tabernaemontana pachysiphon stem bark. Niger. J. Pharm. Res. 2008, 7, 69-75.

143. Ruttoh, E.K.; Bii, C.; Tarus, P.K.; Machocho, A.; Karimi, L.K.; Okemo, P. Antifungal activity of Tabernaemontana stapfiana Britten (Apocynaceae) organic extracts. Pharmacogn. Res. 2009, 1, 387.

144. Hernández-Castro, C.; Diaz-Castillo, F.; Martinez-Gutierrez, M. Ethanol extracts of Cassia grandis and Tabernaemontana cymosa inhibit the in vitro replication of dengue virus serotype 2. Asian Pac. J. Trop. Dis. 2015, 5, 98-106. [CrossRef]

145. Gómez-Calderón, C.; Mesa-Castro, C.; Robledo, S.M.; Gómez-Rangel, S.Y.; Bolivar-Avila, S.; Diaz-Castillo, F.; Martinez-Gutierrez, M. Antiviral effect of compounds derived from the seeds of Mammea americana and Tabernaemontana cymosa on Dengue and Chikungunya virus infections. BMC Complement. Altern. Med. 2017, 17, 1-12. [CrossRef]

146. Twilley, D.; Langhansová, L.; Palaniswamy, D.; Lall, N. Evaluation of traditionally used medicinal plants for anticancer, antioxidant, anti-inflammatory and anti-viral (HPV-1) activity. S. Afr. J. Bot. 2017, 112, 494-500. [CrossRef]

147. Brandão, G.C.; Kroon, E.G.; dos Santos, J.R.; Stehmann, J.R.; Lombardi, J.A.; de Oliveira, A.B. Antiviral activity of plants occurring in the state of Minas Gerais (Brazil): Part III. J. Chem. Pharm. Res. 2011, 3, 223-236.

148. Díaz Castillo, F.; Morelos Cardona, S.M.; Carrascal Medina, M.; Pájaro González, Y.; Gómez Estrada, H. Actividad larvicida de extractosetanólicos de Tabernaemontana cymosa y Trichiliahirta sobrelarvas de estadio III y IV de Aedes aegypti (Diptera: Culicidae). Rev. Cuba. Plant Med. 2012, 17, 256-267. [CrossRef]

149. Marathe, N.; Rasane, M.; Kumar, H.; A Patwardhan, A.; Shouche, Y.S.; Diwanay, S.S. In vitro antibacterial activity of Tabernaemontana alternifolia (Roxb) stem bark aqueous extracts against clinical isolates of methicillin resistant Staphylococcus aureus. Ann. Clin. Microbiol. Antimicrob. 2013, 12, 26. [CrossRef] [PubMed]

150. Gindri, A.L.; Boligon, A.A.; Mario, D.N.; Frohlich, J.K.; de Brum, T.F.; Alves, S.H.; Athayde, M.L. Potencial anti-microbiano do extratobruto e frações das folhas de Tabernaemontana catharinensis A. DC. Rev. Contexto Saúde 2013, 11, $1213-1216$.

151. Fonseca, T.L.; Von Groll, A.; Leitão, G.G.; Scaini, C.J.; Ramos, D.F.; Silva, P.E.A. Antimycobacterial Vegetal Extracts against Mycobacterium fortuitum and Mycobacterium malmoense. Vittalle 2008, 20, 65-71.

152. Ramos, D.F.; Leitão, G.G.; Costa, F.D.N.; Abreu, L.; Villarreal, J.V.; Leitão, S.G.; Fernández, S.L.S.Y.; Da Silva, P.E.A. Investigation of the antimycobacterial activity of 36 plant extracts from the brazilian Atlantic Forest. Rev. Bras. Ciências Farm. 2008, 44, 669-674. [CrossRef]

153. Guida, A.; Battista, G.D.; Bargardi, S. Actividad antibacteriana de alcaloides de Tabernaemontana catharinensis A. DC. ARS Pharm. 2003, 44, 167-173. [CrossRef]

154. Froeder, A.L.F.; Nunes, L.; Pappis, L.; Boligon, A.A.; de Brum, T.F.; Dalmolin, T.V.; Bonez, P.C.; Campos, M.M.A.; Athayde, M.L. Atividad eantimicrobiana do extratobrutoefrações das folhas de Tabernaemontana catharinensis frente à Mycobacterium tuberculosis. Rev. Fitoter. 2012, 12, 176.

155. Van Beek, T.; Deelder, A.; Verpoorte, R.; Svendsen, A. Antimicrobial, Antiamoebic and Antiviral Screening of some Tabernaemontana Species. Planta Med. 1984, 50, 180-185. [CrossRef]

156. Rastogi, N.; Abaul, J.; Goh, K.S.; Devallois, A.; Philogène, E.; Bourgeois, P. Antimycobacterial activity of chemically defined natural substances from the Caribbean flora in Guadeloupe. FEMS Immunol. Med. Microbiol. 1998, 20, 267-273. [CrossRef]

157. Mohamad, S.; Zin, N.M.; Wahab, H.A.; Ibrahim, P.; Sulaiman, S.F.; Zahariluddin, A.S.M.; Noor, S.S.M. Antituberculosis potential of some ethnobotanically selected Malaysian plants. J. Ethnopharmacol. 2011, 133, 1021-1026. [CrossRef]

158. Bakhtiar, M.; Izzati, M.N.; Darnis, D. Cytotoxic and antimicrobial activities of alkaloids from Tabernaemontana corymbose.. In Proceedings of the 5th AASP Conference, Bandung, Indonesia, 16-19 June 2011.

159. Ashikur, R.M.; Hasanuzzaman, M.; Mofizur, R.M.; Zahan, S.I.; Muhuri, R.S. Evaluation of antibacterial activity of study of leaves of Tabernaemontana divaricata (L.). Int. Res. J. Pharm. 2011, 2, 123-127.

160. Thombre, R.; Jagtap, R.; Patil, N. Evaluation of phytoconstituents, antibacterial, antioxidant and cytotoxic activity of Vitex negundo L. and Tabernaemontana divaricata L. Int. J. Pharm. Biol. Sci. 2013, 4, 389-396.

161. Gopinath, S.M.; Suneetha, T.B.; Mruganka, V.D.; Ananda, S. Evaluation of antibacterial activity of Tabernaemontana divaricata (L.) leaves against the causative organisms of bovine mastitis. Int. J. Phytochem. Pharmacol. Res. 2011, 1, 211-213.

162. Pushpa, B.; Latha, K.P.; Vaidya, V.P.; Shruthi, A.; Shweath, C. In vitro anthelmintic activity of leaves extracts of Tabernaemontana coronaria. Int. J. Chem. Tech. Res. 2011, 3, 1788-1790.

163. Shaker, I.A.; Inampudi, S.; Rayapu, V. Antimicrobial activity assay of Tabernaemontana coronaria. Int. J. Bioassays (IJB) 2012, 1, 4-5.

164. Haniffa, M.A.; Kavitha, K. Antibacterial activity of medicinal herbs against the fish pathogen Aeromonas hydrophila. J. Agric. Technol. 2012, 8, 205-211.

165. Sumitha, J.; Padmalatha, C.; Singh, A.R. Antibacterial efficacy of Moringa oleifera and Tabernaemontana divaricata flower extracts on occular pathogens. Int. J. Curr. Microbiol. Appl. Sci. 2015, 4, 203-216.

166. Raja, A.; AshokKumar, S.; Marthandam, R.P.; Jayachandiran, J.; Khatiwada, C.P.; Kaviyarasu, K.; Raman, R.G.; Swaminathan, M. Eco-friendly preparation of zinc oxide nanoparticles using Tabernaemontana divaricata and its photocatalytic and antimicrobial activity. J. Photochem. Photobiol. B Biol. 2018, 181, 53-58. [CrossRef]

167. Zhu, W.-T.; Zhao, Q.; Huo, Z.-Q.; Hao, X.-J.; Yang, M.; Zhang, Y. Taberdivamines A and B, two new quaternary indole alkaloids from Tabernaemontana divaricata. Tetrahedron Lett. 2020, 152400. [CrossRef]

168. Radhika, B. Comparitive Study of Soxhlation and Maceration Extracts of Tabernaemontana divaricta Leaves for Antibacterial Activity. J. Nat. Prod. Plant Resour. 2017, 7, 34-39. 
169. Luo, X.; Pires, D.; Aínsa, J.A.; Gracia, B.; Mulhovo, S.; Duarte, A.; Anes, E.; Ferreira, M.J.U. Antimycobacterial evaluation and preliminary phytochemical investigation of selected medicinal plants traditionally used in Mozambique. J. Ethnopharmacol. 2011, 137, 114-120. [CrossRef] [PubMed]

170. Graham, J.; Pendland, S.; Prause, J.; Danzinger, L.; Vigo, J.S.; Cabieses, F.; Farnsworth, N. Antimycobacterial evaluation of Peruvian plants. Phytomedicine 2003, 10, 528-535. [CrossRef] [PubMed]

171. Duru, C.M.; Mbata, T.I. The antimicrobial activities and phytochemical screening of ethanolic leaf extracts of Hedrantherabarteri Hook and Tabernaemontana pachysiphon Stapf. J. Dev. Biol. Tissue Eng. 2010, 2, 1-4.

172. Ruttoh, E.; Tarus, P.; Bii, C.; Machocho, A.; Karimi, L.; Okemo, P. Antibacterial activity of Tabernaemontana stapfiana Britten (apocynaceae) extracts. Afr. J. Tradit. Complement. Altern. Med. 2009, 6, 186. [CrossRef]

173. Gakuya, D.W.; Itonga, S.; Mbaria, J.; Muthee, J.; Musau, J. Ethnobotanical survey of biopesticides and other medicinal plants traditionally used in Meru central district of Kenya. J. Ethnopharmacol. 2013, 145, 547-553. [CrossRef]

174. Jamil, S.; Ahmad, S.; Akhtar, J.; Alam, K. Antiamoebic plants used in Unani System of Medicine. Nat. Prod. Radiance 2003, 2, 1-6.

175. Moghadamtousi, S.Z.; Kadir, H.A.; Hassandarvish, P.; Tajik, H.; Abubakar, S.; Zandi, K. A Review on Antibacterial, Antiviral, and Antifungal Activity of Curcumin. BioMed Res. Int. 2014, 2014, 186864. [CrossRef]

176. Wise, R.; Hart, T.; Cars, O.; Streulens, M.; Helmuth, R.; Huovinen, P.; Sprenger, M. Antimicrobial resistance. BMJ 1998, 317, 609-610. [CrossRef] [PubMed]

177. Malla, B.; Gauchan, D.P.; Chhetri, R.B. An ethnobotanical study of medicinal plants used by ethnic people in Parbat district of western Nepal. J. Ethnopharmacol. 2015, 165, 103-117. [CrossRef] [PubMed]

178. Singh, M.; Pandey, N.; Agnihotri, V.; Singh, K.; Pandey, A. Antioxidant, antimicrobial activity and bioactive compounds of Bergenia ciliata Sternb.: A valuable medicinal herb of Sikkim Himalaya. J. Tradit. Complement. Med. 2017, 7, 152-157. [CrossRef]

179. Singh, S.; Bharti, N.; Mohapatra, P.P. Chemistry and Biology of Synthetic and Naturally Occurring Antiamoebic Agents. Chem. Rev. 2009, 109, 1900-1947. [CrossRef]

180. Sharma, P.; Sharma, J.D. A review of plant species assessed in vitro for antiamoebic activity or both antiamoebic and antiplasmodial properties. Phytother. Res. Int. J. Pharmacol. Toxicol. Eval. Nat. Prod. Deriv. 2001, 15, 1-17. [CrossRef]

181. Hayat, F.; Azam, A.; Shin, D.-Y. Recent progress on the discovery of antiamoebic agents. Bioorg. Med. Chem. Lett. 2016, 26, 5149-5159. [CrossRef] [PubMed]

182. Negi, B.; Poonan, P.; Ansari, M.F.; Kumar, D.; Aggarwal, S.; Singh, R.; Azam, A.; Rawat, D.S. Synthesis, antiamoebic activity and docking studies of metronidazole-triazole-styryl hybrids. Eur. J. Med. Chem. 2018, 150, 633-641. [CrossRef] [PubMed]

183. McGaw, L.; Jäger, A.; Van Staden, J. Antibacterial, anthelmintic and anti-amoebic activity in South African medicinal plants. J. Ethnopharmacol. 2000, 72, 247-263. [CrossRef]

184. Tamokou, J.-D.-D.; Kuete, V. Mutagenicity and Carcinogenicity of African Medicinal Plants. Toxicol. Surv. Afr. Med. Plants 2014, 1, 277-322. [CrossRef]

185. Reddy, L.; Odhav, B.; Bhoola, K. Natural products for cancer prevention: A global perspective. Pharmacol. Ther. 2003, 99, 1-13. [CrossRef]

186. Sudarshan, V.K.; Mookiah, M.R.K.; Acharya, U.R.; Chandran, V.; Molinari, F.; Fujita, H.; Ng, K.H. Application of wavelet techniques for cancer diagnosis using ultrasound images: A Review. Comput. Biol. Med. 2016, 69, 97-111. [CrossRef]

187. World Heath Organization. Available online: https://www.who.int/data/gho/data/themes/topics/topic-details/GHO/worldhealth-statistics (accessed on 17 September 2018).

188. Bray, F.; Ferlay, J.; Soerjomataram, I.; Siegel, R.L.; Torre, L.A.; Jemal, A. Global cancer statistics 2018: GLOBOCAN estimates of incidence and mortality worldwide for 36 cancers in 185 countries. CA Cancer J. Clin. 2018, 68, 394-424. [CrossRef]

189. Rosales, P.F.; Marinho, F.F.; Gower, A.; Chiarello, M.; Canci, B.T.; Roesch-Ely, M.; Paula, F.R.; Moura, S. Bio-guided search of active indole alkaloids from Tabernaemontana catharinensis: Antitumour activity, toxicity in silico and molecular modelling studies. Bioorg. Chem. 2019, 85, 66-74. [CrossRef]

190. Gillet, J.P.; Gottesman, M.M. Mechanisms of multidrug resistance in cancer. In Multi-Drug Resistance in Cancer; Humana Press: Totowa, NJ, USA, 2010; Volume 4, pp. 47-76. [CrossRef]

191. Kuete, V.; Saeed, M.E.; Kadioglu, O.; Börtzler, J.; Khalid, H.; Greten, H.J.; Efferth, T. Pharmacogenomic and molecular docking studies on the cytotoxicity of the natural steroid wortmannin against multidrug-resistant tumor cells. Phytomedicine 2015, 22, 120-127. [CrossRef]

192. Ferreira, M.-J.U.; Paterna, A. Monoterpene indole alkaloids as leads for targeting multidrug resistant cancer cells from the African medicinal plant Tabernaemontana elegans. Phytochem. Rev. 2019, 18, 971-987. [CrossRef]

193. Thind, T.S.; Agrawal, S.K.; Saxena, A.; Arora, S. Studies on cytotoxic, hydroxyl radical scavenging and topoisomerase inhibitory activities of extracts of Tabernaemontana divaricata (L.) R.Br. ex Roem. and Schult. Food Chem. Toxicol. 2008, 46, $2922-2927$. [CrossRef] [PubMed]

194. Jordan, M.A.; Thrower, D.; Wilson, L. Mechanism of inhibition of cell proliferation by Vinca alkaloids. Cancer Res. 1991, 51, 2212-2222.

195. Nobili, S.; Lippi, D.; Witort, E.; Donnini, M.; Bausi, L.; Mini, E.; Capaccioli, S. Natural compounds for cancer treatment and prevention. Pharmacol. Res. 2009, 59, 365-378. [CrossRef]

196. Ma, X.; Wang, Z. Anticancer drug discovery in the future: An evolutionary perspective. Drug Discov. Today 2009, 14, 1136-1142. [CrossRef] 
197. Bhanot, A.; Sharma, R.; Noolvi, M.N. Natural sources as potential anti-cancer agents: A Review. Int. J. Phytomed. 2011, 3, 9-26.

198. Khazir, J.; Mir, B.A.; Pilcher, L.A.; Riley, D.L. Role of plants in anticancer drug discovery. Phytochem. Lett. 2014, 7, 173-181. [CrossRef]

199. Zhang, B.-J.; Teng, X.-F.; Bao, M.-F.; Zhong, X.-H.; Ni, L.; Cai, X.-H. Cytotoxic indole alkaloids from Tabernaemontana officinalis. Phytochemistry 2015, 120, 46-52. [CrossRef]

200. Zhou, S.-Y.; Zhou, T.-L.; Qiu, G.; Huan, X.; Miao, Z.-H.; Yang, S.-P.; Cao, S.; Fan, F.; Cai, Y.-S. Three New Cytotoxic Monoterpenoid Bisindole Alkaloids from Tabernaemontana bufalina. Planta Med. 2018, 84, 1127-1133. [CrossRef]

201. Chaturvedula, V.S.P.; Sprague, S.; Schilling, J.K.; Kingston, D.G.I. New Cytotoxic Indole Alkaloids from Tabernaemontana calcarea from the Madagascar Rainforest1. J. Nat. Prod. 2003, 66, 528-531. [CrossRef]

202. De Almeida, L.; Cintra, A.C.; Veronese, E.L.; Nomizo, A.; Franco, J.J.; Arantes, E.C.; Giglio, J.R.; Sampaio, S.V. Anticrotalic and antitumoral activities of gel filtration fractions of aqueous extract from Tabernaemontana catharinensis (Apocynaceae). Comp. Biochem. Physiol. Part C Toxicol. Pharmacol. 2004, 137, 19-27. [CrossRef]

203. Pereira, C.G.; Marques, M.O.M.; Barreto, A.S.; Siani, A.C.; Fernandes, E.C.; Meireles, M.A.A. Extraction of indole alkaloids from Tabernaemontana catharinensis using supercritical $\mathrm{CO}^{2+}$ ethanol: An evaluation of the process variables and the raw material origin. J. Supercrit. Fluids 2004, 30, 51-61. [CrossRef]

204. Rizo, W.F.; Ferreira, L.E.; Colnaghi, V.; Martins, J.S.; Franchi, L.P.; Takahashi, C.S.; Beleboni, R.O.; Marins, M.; Pereira, P.S.; Fachin, A.L. Cytotoxicity and genotoxicity of coronaridine from Tabernaemontana catharinensis A.DC in a human laryngeal epithelial carcinoma cell line (Hep-2). Genet. Mol. Biol. 2013, 36, 105-110. [CrossRef]

205. Rosales, P.F.; Gower, A.; Benitez, M.L.R.; Pacheco, B.S.; Segatto, N.V.; Roesch-Ely, M.; Collares, T.; Seixas, F.K.; Moura, S. Extraction, isolation and in vitro evaluation of affinisine from Tabernaemontana catharinensis in human melanoma cells. Bioorg. Chem. 2019, 90, 103079. [CrossRef]

206. Ndongo, J.T.; Mbing, J.N.; Tala, M.F.; Monteillier, A.; Pegnyemb, D.E.; Cuendet, M.; Laatsch, H. Indoline alkaloids from Tabernaemontana contorta with cancer chemopreventive activity. Phytochemistry 2017, 144, 189-196. [CrossRef]

207. Lim, K.-H.; Hiraku, O.; Komiyama, K.; Kam, T.-S. Jerantinines A-G, Cytotoxic Aspidosperma Alkaloids from Tabernaemontana corymbosa. J. Nat. Prod. 2008, 71, 1591-1594. [CrossRef] [PubMed]

208. Frei, R.; Staedler, D.; Raja, A.; Franke, R.; Sasse, F.; Gerber-Lemaire, S.; Waser, J. Total Synthesis and Biological Evaluation of Jerantinine E. Angew. Chem. Int. Ed. 2013, 52, 13373-13376. [CrossRef] [PubMed]

209. Kam, T.-S.; Sim, K.-M.; Koyano, T.; Toyoshima, M.; Hayashi, M.; Komiyama, K. Conodiparines A-D, new bisindoles from Tabernaemontana. Reversal of vincristine-resistance with cultured cells. Bioorg. Med. Chem. Lett. 1998, 8, 1693-1696. [CrossRef]

210. Raja, V.J.; Lim, K.-H.; Leong, C.-O.; Kam, T.-S.; Bradshaw, T.D. Novel antitumour indole alkaloid, Jerantinine A, evokes potent G2/M cell cycle arrest targeting microtubules. Investig. New Drugs 2014, 32, 838-850. [CrossRef]

211. Sim, D.S.-Y.; Chong, K.-W.; Nge, C.-E.; Low, Y.-Y.; Sim, K.-S.; Kam, T.-S. Cytotoxic Vobasine, Tacaman, and Corynanthe-Tryptamine Bisindole Alkaloids from Tabernaemontana and Structure Revision of Tronoharine. J. Nat. Prod. 2014, 77, 2504-2512. [CrossRef] [PubMed]

212. Lim, K.-H.; Raja, V.J.; Bradshaw, T.D.; Lim, S.-H.; Low, Y.-Y.; Kam, T.-S. Ibogan, Tacaman, and Cytotoxic Bisindole Alkaloids from Tabernaemontana. Cononusine, an Iboga Alkaloid with Unusual Incorporation of a Pyrrolidone Moiety. J. Nat. Prod. 2015, 78, 1129-1138. [CrossRef]

213. Ma, K.; Wang, J.-S.; Luo, J.; Yang, M.-H.; Kong, L. Tabercarpamines A-J, Apoptosis-Inducing Indole Alkaloids from the Leaves of Tabernaemontana corymbosa. J. Nat. Prod. 2014, 77, 1156-1163. [CrossRef] [PubMed]

214. Ma, K.; Wang, J.-S.; Luo, J.; Yang, M.-H.; Yao, H.; Sun, H.-B.; Kong, L.-Y. Bistabercarpamines A and B, first vobasinyl-chippiine-type bisindole alkaloid from Tabernaemontana corymbosa. Tetrahedron Lett. 2014, 55, 101-104. [CrossRef]

215. Zhang, Y.; Guo, L.; Yang, G.; Guo, F.; Di, Y.; Li, S.; Chen, D.; Hao, X.-J. New vobasinyl-ibogan type bisindole alkaloids from Tabernaemontana corymbosa. Fitoterapia 2015, 100, 150-155. [CrossRef]

216. Yuan, Y.-X.; Zhang, Y.; Guo, L.-L.; Wang, Y.-H.; Goto, M.; Morris-Natschke, S.L.; Lee, K.-H.; Hao, X. Tabercorymines A and B, Two Vobasinyl-Ibogan-Type Bisindole Alkaloids from Tabernaemontana corymbosa. Org. Lett. 2017, 19, 4964-4967. [CrossRef]

217. Zhang, Y.; Yuan, Y.-X.; Goto, M.; Guo, L.-L.; Li, X.-N.; Morris-Natschke, S.L.; Lee, K.-H.; Hao, X.-J. Taburnaemines A-I, Cytotoxic Vobasinyl-Iboga-Type Bisindole Alkaloids from Tabernaemontana corymbosa. J. Nat. Prod. 2018, 81, 562-571. [CrossRef]

218. Al-Hayali, M.Z.K. Characterisation of Anticancer Properties of a Novel and Naturally Isolated Bisindole Alkaloid, Conofolidine. Ph.D. Thesis, University of Nottingham, Nottinghamshire, UK, 2018.

219. Lee, C.; Houghton, P. Cytotoxicity of plants from Malaysia and Thailand used traditionally to treat cancer. J. Ethnopharmacol. 2005, 100, 237-243. [CrossRef] [PubMed]

220. Selvakumar, S.; Kumar, A. Antiproliferative efficacy of Tabernaemontana divaricata against HEP2 cell line and Vero cell line. Pharmacogn. Mag. 2015, 11, 46-52. [CrossRef]

221. Hullatti, K.; Pathade, N.; Mandavkar, Y.; Godavarthi, A.; Biradi, M. Bioactivity-guided isolation of cytotoxic constituents from three medicinal plants. Pharm. Biol. 2013, 51, 601-606. [CrossRef]

222. Poornima, K.; Gopalakrishnan, V.K. Anticancer Activity of Tabernaemontana coronaria against Carcinogen Induced Clear Cell Renal Cell Carcinoma. Chin. J. Biol. 2014, 2014, 584074. [CrossRef]

223. Bao, M.-F.; Yan, J.-M.; Cheng, G.-G.; Li, X.-Y.; Liu, Y.-P.; Li, Y.; Cai, X.-H.; Luo, X.-D. Cytotoxic Indole Alkaloids from Tabernaemontana divaricata. J. Nat. Prod. 2013, 76, 1406-1412. [CrossRef] 
224. Guo, L.-L.; He, H.-P.; Di, Y.-T.; Li, S.-F.; Cheng, Y.-Y.; Yang, W.; Li, Y.; Yu, J.-P.; Zhang, Y.; Hao, X.-J. Indole alkaloids from Ervatamia chinensis. Phytochemistry 2012, 74, 140-145. [CrossRef]

225. Gunasekera, S.P.; Cordell, G.; Farnsworth, N.R. Anticancer indole alkaloids of Ervatamia heyneana. Phytochemistry 1980, 19, 1213-1218. [CrossRef]

226. Ohishi, K.; Toume, K.; Arai, M.A.; Sadhu, S.K.; Ahmed, F.; Ishibashi, M. Coronaridine, an iboga type alkaloid from Tabernaemontana divaricata, inhibits the Wnt signaling pathway by decreasing $\beta$-catenin mRNA expression. Bioorg. Med. Chem. Lett. 2015, 25, 3937-3940. [CrossRef]

227. Mavuduru, S.; Kriti, K.; Mishra, A.; Ghosh, M. Isolation of anticancer agents from Tabernaemontana divaricata (L.) R. Br. ex Roem. \& Schult. Sci. Forum. 2017, 1-5. [CrossRef]

228. Dantu, A.S.; Shankarguru, P.; Ramya, D.D.; Vedha, H.B. Evaluation of in vitro anticancer activity of hydroalcoholic extract of Tabernaemontana divaricata. Asian J. Pharm. Clin. Res. 2012, 5, 59-61.

229. Doshi, G.M.; Kanad, P.P.; Azad, N.; Desai, A.; Somani, R.R.; Chaskar, P.K. In vitro Cytotoxicity Studies on Tabernaemontana divaricata leaves extracts by sulforhodamine B assay method. Int. J. Pharm. Sci. Rev. Res. 2017, 45, 179-182.

230. Mansoor, T.A.; Ramalho, R.M.; Mulhovo, S.; Rodrigues, C.M.P.; Ferreira, M.-J.U. Induction of apoptosis in HuH-7 cancer cells by monoterpene and $\beta$-carboline indole alkaloids isolated from the leaves of Tabernaemontana elegans. Bioorg. Med. Chem. Lett. 2009, 19, 4255-4258. [CrossRef] [PubMed]

231. Mansoor, T.A.; Borralho, P.M.; Dewanjee, S.; Mulhovo, S.; Rodrigues, C.M.; Ferreira, M.-J.U. Monoterpene bisindole alkaloids, from the African medicinal plant Tabernaemontana elegans, induce apoptosis in HCT116 human colon carcinoma cells. J. Ethnopharmacol. 2013, 149, 463-470. [CrossRef] [PubMed]

232. Zaima, K.; Koga, I.; Iwasawa, N.; Hosoya, T.; Hirasawa, Y.; Kaneda, T.; Ismail, I.S.; Lajis, N.H.; Morita, H. Vasorelaxant activity of indole alkaloids from Tabernaemontana dichotoma. J. Nat. Med. 2013, 67, 9-16. [CrossRef] [PubMed]

233. Meschini, S.; Marra, M.; Calcabrini, A.; Federici, E.; Galeffi, C.; Arancia, G. Voacamine, a bisindolic alkaloid from Peschiera fuchsiaefolia, enhances the cytotoxic effect of doxorubicin on multidrug-resistant tumor cells. Int. J. Oncol. 2003, 23, 1505-1513. [CrossRef] [PubMed]

234. Bradacs, G.; Maes, L.; Heilmann, J. In vitro cytotoxic, antiprotozoal and antimicrobial activities of medicinal plants from Vanuatu. Phytother. Res. 2010, 24, 800-809. [CrossRef]

235. Suganthy, N.; Pandian, S.K.; Devi, K.P. Cholinesterase inhibitors from plants: Possible treatment strategy for neurological disorders-a review. Int. J. Biomed. Pharm. Sci. 2009, 3, 87-103.

236. Pereira, D.M.; Ferreres, F.; Oliveira, J.M.; Gaspar, L.; Faria, J.; Valentão, P.; Sottomayor, M.; Andrade, P.B. Pharmacological effects of Catharanthus roseus root alkaloids in acetylcholinesterase inhibition and cholinergic neurotransmission. Phytomedicine 2010, 17, 646-652. [CrossRef]

237. Chaiyana, W.; Schripsema, J.; Ingkaninan, K.; Okonogi, S. 3'-R/S-Hydroxyvoacamine, a potent acetylcholinesterase inhibitor from Tabernaemontana divaricata. Phytomedicine 2013, 20, 543-548. [CrossRef]

238. Chattipakorn, S.C.; Pongpanparadorn, A.; Pratchayasakul, W.; Pongchaidacha, A.; Ingkaninan, K.; Chattipakorn, N. Tabernaemontana divaricata extract inhibits neuronal acetylcholinesterase activity in rats. J. Ethnopharmacol. 2007, 110, 61-68. [CrossRef]

239. Rawa, M.S.A.; Hassan, Z.; Murugaiyah, V.; Nogawa, T.; Wahab, H.A. Anti-cholinesterase potential of diverse botanical families from Malaysia: Evaluation of crude extracts and fractions from liquid-liquid extraction and acid-base fractionation. J. Ethnopharmacol. 2019, 245, 112160. [CrossRef]

240. Adewusi, E.A.; Steenkamp, V. In vitro screening for acetylcholinesterase inhibition and antioxidant activity of medicinal plants from southern Africa. Asian Pac. J. Trop. Med. 2011, 4, 829-835. [CrossRef]

241. Ingkaninan, K.; Temkitthawon, P.; Chuenchom, K.; Yuyaem, T.; Thongnoi, W. Screening for acetylcholinesterase inhibitory activity in plants used in Thai traditional rejuvenating and neurotonic remedies. J. Ethnopharmacol. 2003, 89, 261-264. [CrossRef]

242. Andrade, M.T.; Lima, J.A.; Pinto, A.C.; Rezende, C.M.; Carvalho, M.P.; Epifanio, R.A. Indole alkaloids from Tabernaemontana australis (Müell. Arg) Miers that inhibit acetylcholinesterase enzyme. Bioorg. Med. Chem. 2005, 13, 4092-4095. [CrossRef]

243. Mukherjee, P.K.; Kumar, V.; Mal, M.; Houghton, P.J. Acetylcholinesterase inhibitors from plants. Phytomedicine 2007, 14, 289-300. [CrossRef]

244. Ranjan, N.; Kumari, M. Acetylcholinesterase inhibition by medicinal plants: A Review. Ann. Plant Sci. 2017, 6, 1640-1644. [CrossRef]

245. Athipornchai, A.; Ketpoo, P.; Saeeng, R. Acetylcholinesterase Inhibitor from Tabernaemontana pandacaqui Flowers. Nat. Prod. Commun. 2020, 15. [CrossRef]

246. Wijayabandara, M.D.J.; Khan, S.N.; Choudhary, M.I. Novel Alpha-Glucosidase Inhibitor from Tabernaemontana dichotoma. U.S. Patent Application No. 11/553,465, 1 May 2008.

247. Nakdook, W.; Khongsombat, O.; Taepavarapruk, P.; Taepavarapruk, N.; Ingkaninan, K. The effects of Tabernaemontana divaricata root extract on amyloid $\beta$-peptide 25-35 peptides induced cognitive deficits in mice. J. Ethnopharmacol. 2010, 130, 122-126. [CrossRef] [PubMed]

248. Singh, M.K.; Usha, R.; Hithayshree, K.R.; Sukumaran, B.O. Hemostatic potential of latex proteases from Tabernaemontana divaricata (L.) R. Br. ex. Roem. and Schult. and Artocarpus altilis (Parkinson ex. F.A. Zorn) Forsberg. J. Thromb. Thrombolysis 2015, 39, 43-49. [CrossRef] 
249. Alper, K.; Reith, M.E.A.; Sershen, H. Ibogaine and the inhibition of acetylcholinesterase. J. Ethnopharmacol. 2012, 139, 879-882. [CrossRef]

250. Khan, M.S.A.; Jais, A.M.M.; Afreen, A. Prostaglandin Analogous and Antioxidant Activity Mediated Gastroprotective Action of Tabernaemontana divaricate (L.) R. Br. Flower Methanolic Extract against Chemically Induced Gastric Ulcers in Rats. BioMed Res. Int. 2013, 2013, 185476. [CrossRef]

251. Kanthlal, S.K.; Kumar, B.A.; Joseph, J.; Aravind, R.; Frank, P.R. Amelioration of oxidative stress by Tabernamontana divaricata on alloxan-induced diabetic rats. Ann. Sci. Life 2014, 33, 222-228. [CrossRef]

252. Kojima, I.; Umezawa, K. Conophylline: A novel differentiation inducer for pancreatic $\beta$ cells. Int. J. Biochem. Cell Biol. 2006, 38, 923-930. [CrossRef]

253. Fujii, M.; Takei, I.; Umezawa, K. Antidiabetic effect of plant extract containing conophylline by oral administration in streptozotocin-treated and Goto-Kakizaki rats. Biomed. Pharmacother. 2009, 63, 710-716. [CrossRef] [PubMed]

254. Núñez, V.; Otero, R.; Barona, J.; Fonnegra, R.; Jiménez, S.; Osorio, R.G.; Quintana, J.C.; Díaz, A. Inhibition of the Toxic Effects of Lachesis muta, Crotalus durissus cumanensis and Micrurus mipartitus Snake Venoms by Plant Extracts. Pharm. Biol. 2004, 42, 49-54. [CrossRef]

255. Vineetha, M.S.; Bhavya, J.; More, S.S. Inhibition of pharmacological and toxic effects of Echiscarinatus venom by Tabernaemontana alternifolia root extract. Indian J. Nat. Prod. Res. 2019, 10, 48-58.

256. Devaraj, P.; Aarti, C.; Kumari, P. Synthesis and characterisation of silver nanoparticles using Tabernaemontana divaricata and its cytotoxic activity against MCF7 cell line. Int. J. Pharm. Pharmaceu Sci. 2014, 6, 86-90.

257. Lateef, A.; Folarin, B.I.; Oladejo, S.M.; Akinola, P.O.; Beukes, L.S.; Gueguim-Kana, E.B. Characterization, antimicrobial, antioxidant, and anticoagulant activities of silver nanoparticles synthesized from Petiveria alliacea L. leaf extract. Prep. Biochem. Biotechnol. 2018, 48, 646-652. [CrossRef]

258. Chouhan, N. Silver nanoparticles: Synthesis, characterization and applications. In Silver Nanoparticles-Fabrication, Characterization and Applications; Maaz, K., Ed.; IntechOpen: Rajasthan, India, 2018. [CrossRef]

259. Barberia-Roque, L.; Gámez-Espinosa, E.; Viera, M.; Bellotti, N. Assessment of three plant extracts to obtain silver nanoparticles as alternative additives to control biodeterioration of coatings. Int. Biodeterior. Biodegrad. 2018, 141, 52-61. [CrossRef]

260. Gorchev, H.G.; Ozolins, G. WHO guidelines for drinking-water quality. WHO Chron. 2011, 38, $104-108$.

261. Mittal, A.K.; Chisti, Y.; Banerjee, U.C. Synthesis of metallic nanoparticles using plant extracts. Biotechnol. Adv. 2013, 31, 346-356. [CrossRef]

262. Thakkar, K.N.; Mhatre, S.S.; Parikh, R.Y. Biological synthesis of metallic nanoparticles. Nanomed. Nanotechnol. Biol. Med. 2010, 6, 257-262. [CrossRef] [PubMed]

263. Singh, A.K. Engineered Nanoparticles: Structure, Properties and Mechanisms of Toxicity; Academic Press: London, UK, 2015.

264. Sigamoney, M.; Shaik, S.; Govender, P.; Krishna, S. Sershen African leafy vegetables as bio-factories for silver nanoparticles: A case study on Amaranthus dubius C Mart. Ex Thell. S. Afr. J. Bot. 2016, 103, 230-240. [CrossRef]

265. Banerjee, J.; Narendhirakannan, R.T. Biosynthesis of silver nanoparticles from Syzygiumcumini (L.) seed extract and evaluation of their in vitro antioxidant activities. Dig. J. Nanomater. Biostruct. 2011, 6, 961-968.

266. Safavi, K. Evaluation of using nanomaterial in tissue culture media and biological activity. In Proceedings of the Second International Conference on Ecological, Environmental and Biological Sciences, Bali, Idonesia, 13-14 October 2012.

267. Anbukkarasi, M.; Thomas, P.A.; Teresa, P.A.; Anand, T.; Geraldine, P. Comparison of the efficacy of a Tabernaemontana divaricata extract and of biosynthesized silver nanoparticles in preventing cataract formation in an in-vivo system of selenite-induced cataractogenesis. Biocatal. Agric. Biotechnol. 2020, 23, 101475. [CrossRef] 